\title{
Chemical Recycling of Plastic Waste: Comparative Evaluation of Environmental and Economic Performances of Gasification- and Incineration-based Treatment for Lightweight Packaging Waste
}

\author{
Raoul Voss $^{1,2,3} \cdot$ Roh Pin Lee $^{1} \mathbb{D} \cdot$ Magnus Fröhling $^{3}(\mathbb{D}$
}

Received: 27 July 2021 / Accepted: 15 December 2021 / Published online: 23 February 2022

(C) The Author(s) 2022

\begin{abstract}
Chemical recycling (CR) - in enabling the use of plastic waste back as secondary carbon feedstock for production - could play a complementary role to mechanical recycling in supporting the transformation from a linear to a circular carbon economy. To date, research has predominantly focused on assessing technological aspects associated with CR of pure plastic waste streams. Little is known about its potential for treating low-quality and mixed plastic waste fractions which are unsuitable for conventional recycling and are currently incinerated. To address this gap, this investigation utilizes an integrated approach comprising of life cycle assessment and techno-economic analysis to evaluate the environmental and economic performance of CR of lightweight packaging waste via waste gasification compared to direct and indirect incineration in Germany. Results show that CR can contribute significantly - irrespective of the energy mix - to reducing climate change, terrestrial acidification, and fossil resource scarcity. In terms of economic performance, findings suggest that while $\mathrm{CR}$ requires higher capital investment, a multi-pronged approach which encompasses upscaling, waiver of carbon dioxide certificate costs, and price premium for $\mathrm{CR}$ products could increase profitability of $\mathrm{CR}$ to incineration. This study provides empirical support for the potential contribution of CR to complement existing strategies to combat the plastic waste challenge, and insights into market conditions which could promote its economic attractiveness. Additionally, it provides comprehensive inventory data for conventional and alternative waste treatment plants for lightweight packaging waste to inform future research on systemic assessment of CR technologies and their contributions to a circular economy.
\end{abstract}

Keywords Circular carbon economy $\cdot$ Life cycle assessment (LCA) $\cdot$ Techno-economic analysis (TEA) $\cdot$ Waste incineration $\cdot$ Plastic waste

\section{Abbreviations \\ $A P \quad$ Acidification potential \\ CEPCI Chemical Engineering Plant Costs Index}

Raoul Voss

raoul-lukas.voss@iec.tu-freiberg.de

Extended author information available on the last page of the article 


$\begin{array}{ll}C N & \text { Climate neutral } \\ C R & \text { Chemical recycling } \\ D P P & \text { Dynamic payback period } \\ E P S & \text { Energy provision scenario } \\ E R E G & \text { Environmental regulation } \\ E S & \text { Economic scenario } \\ F C I & \text { Fixed capital investment } \\ F F P & \text { Fossil fuel potential } \\ G H G & \text { Greenhouse gas } \\ G W P & \text { Global warming potential } \\ L C C A & \text { Levelized cost of carbon abatement } \\ L W P & \text { Lightweight packaging } \\ M C & \text { Market conditions } \\ M R F & \text { Materials recovery facility } \\ N P V & \text { Net present value } \\ P R E D & \text { Predominantly renewable energy supply } \\ P S & \text { Plant scaling } \\ R D F & \text { Refuse-derived fuel } \\ S I & \text { Supplementary Information } \\ T C I & \text { Total capital investment } \\ U B A & \text { German Environment Agency } \\ W C & \text { Working capital }\end{array}$

\section{Introduction}

In recent years, the global plastic crisis arising from increasing plastic consumption in combination with improper plastic disposal has captured the global attention and is putting immense pressure on policymakers, science, and industry to react [1]. As a highly versatile and affordable material with a wide range of applications, plastic is integral to applications in diverse sectors ranging from consumables, household \& industrial appliances, medical equipment, communications, to mobility [2]. However, the stability of plastic materials also translates into a serious disposal problem. Improper disposal of plastic waste has led to widely publicized environmental pollution on land and sea, and is associated with adverse effects not only for flora and fauna but also for humans [3-5]. To combat the plastic challenge, policymakers are expected to develop stricter regulations ranging from the reduction of plastic consumption especially for single-use plastics, enhanced eco-design, to higher recycling quota [6,7]. At the same time, science and industry are increasingly in the spotlight to develop sustainable solutions to increase the circularity of plastics [8-12].

In developing solutions and measures to address the plastic crisis, the focus is been increasingly placed on lightweight packaging (LWP) materials. LWP waste represents a mixture of consumable packaging made from polymers, ferrous \& non-ferrous metals, paper \& cardboard, aseptic containers (i.e. beverage cartons), and various composite materials [13]. At 40\%, it accounts for the largest share of the plastic production in Europe [14]. As such, it is not surprising that the environmentally friendly disposal/treatment of LWP waste is a key focus of socio-political debates about the plastic waste challenge, and correspondingly a priority for policymakers [14-16]. According to EUROSTAT [17], a significant share of emerging LWP waste in Europe is treated either via material recycling or 
direct incineration, with the latter being a treatment technique still widely applied in European countries. Incineration reduces waste volume, weight, and pollution potential while generating electricity and/or heat as useful products [18]. Additionally, the extraction of minerals as construction materials and "pure" metals make it an attractive alternative to landfilling [18-22]. However, the downside of incineration is that via the incineration process potentially recyclable carbon-containing LWP fractions such as plastics and cardboard will be converted into greenhouse gas (GHG) emissions. This represents not only a loss of secondary carbon resources which could be channeled back as secondary feedstock for production, it furthermore contributes to global warming [23-25].

Hence, as part of its strategy to support the transition towards a sustainable and efficient economy, the European Union is targeting higher recycling rate of LWP within its New Circular Economy Action Plan [6]. One objective is to further increase the proportion of LWP waste processed in material recovery facilities (MRFs) as a preparatory step for mechanical (material) recycling [7]. Mechanical recycling is defined as methods to convert waste materials into secondary raw materials without changing the basic structure of the material $[19,26]$. Through a thorough separation of individual packaging types, MRFs produce homogeneous and high-quality material streams for recyclate production via mechanical recycling. The use of such recyclates for chemical production instead of the direct incineration of LWP waste promotes the transition from a linear economy (i.e. where plastic waste is incinerated following consumption/utilization) to a circular economy (i.e. circularity) where it is channeled back into the production cycle as a secondary feedstock $[1,27]$. Additionally, an increase in the use of such high-quality domestic plastic waste streams to replace imported fossil feedstock for packaging production also contributes to primary resource conservation and a reduction of $\mathrm{CO}_{2}$ leakages along international supply chains [28]. In binding carbon atoms of carbon-containing LWP waste in products rather than in the form of $\mathrm{CO}_{2}$ emissions after incineration, it furthermore contributes to reducing the carbon footprint of packaging materials and to the achievement of a net-zero GHG emissions society [25, 29].

However, circularity of plastics is easier said than done. Although the EU Directive 94/62/EC states that EU countries must recycle 50\% of all LWP made of plastic by 2025 (and 55\% until 2030) [7], the example of Germany - a country which despite a modern and well-established plastic waste recycling system in the form of the dual system ("Duales System") $[30,31]$ only achieves recycling rates of less than $30 \%$ for post-consumer plastics [32] - points to the limits of mechanical recycling in meeting the ambitious EU goal for packaging recycling. Thus, to increase the circularity of packaging waste and to meet recycling targets, new recycling concepts and technologies are urgently required to complement mechanical recycling [17]. In this context, chemical recycling as an alternative option to incineration of LWP waste which is not mechanically recyclable has been eliciting increasing attention and interest not only from industry and academics, but also from policymakers and the civil society [8-10, 12, 33-35].

The term chemical recycling (CR) is generally used to describe technologies where carboncontaining waste is broken down into its basic chemical building blocks, which can then be used as raw materials for the production of new consumables such as plastics and chemicals $[36,37]$. CR could complement mechanical recycling in increasing the circularity of plastics and supporting the transition from a linear to a circular carbon economy $[1,23,24,29,38$, 39]. However, there is a lack of quantitative data and scientific/technical literature to support a comparative evaluation of the strengths and weaknesses of CR against conventional recycling and energy recovery pathways. The predominant attention today - academic and otherwise - is on technical issues related to CR, with existing literature focusing on new technical 
developments [10, 40-43], life cycle assessments [23, 44-46], as well as energy and material balances [43, 47, 48]. Furthermore, the predominant focus on pure plastic waste streams as potential CR feedstock has led to significant controversy in the socio-political realm as it presents a direct competition with mechanical recycling techniques [9, 49]. Moreover, despite its potential relevance and contribution to plastic circularity, studies that utilize a multi-dimensional and holistic approach (i.e. considering integration in existing production infrastructures and processes) to comparatively evaluate CR of LWP waste against conventional incineration and mechanical recycling options are, to the best of the authors' knowledge, missing. Such insights would be invaluable in contributing to socio-political discussions about the role of CR in the waste hierarchy, especially for the sustainable management of plastic waste [50].

To address these gaps in the extant literature, this research utilizes a case study approach to investigate quantitative impacts associated with CR of LWP waste against conventional LWP waste treatment pathways. It contributes to discussions about LWP waste treatment through extending the focus from an isolated technical evaluation to integrated environmental and economic assessments of CR in Germany. Specifically, the environmental assessment focuses on a life cycle assessment of indicators namely climate change, terrestrial acidification, and fossil resource scarcity. Economic performance is assessed via techno-economic analysis of total capital investment (TCI), net present value (NPV), dynamic payback period (DPP), and levelized cost of carbon abatement (LCCA). The environmental and economic assessments support a comparative evaluation of three LWP waste treatment pathways namely (1) direct incineration, (2) partial incineration, and (3) CR.

Note that in the investigation, it is assumed that both partial incineration and CR are integrated into current best practices whereby homogeneous and high-quality LWP waste streams are first extracted in MRFs for subsequent mechanical recycling. The heterogeneous and lowquality residues from the MRF sorting process are then either incinerated in the partial incineration pathway, or used as raw material for a CR plant. In this way, CR does not compete with mechanical recycling for pure plastic waste streams. Rather, it complements mechanical recycling to raise the recycling quota by presenting a recycling alternative to incineration for residue LWP waste fractions which are not suitable for mechanical recycling [51].

The paper is structured as follows: the "Study Context" section provides detailed information on the study context in Germany. This supports an assessment of the transferability of findings, conclusions, and recommendations of the current study to other research contexts, e.g. to other countries with different waste management systems. The "Methodology" section presents the inventory dataset for this study. In addition to an overview of the characteristics of LWP waste and treatment technology, methodologies utilized for the environmental and economic calculations are also presented. The "Results and Discussion" section presents the results and discusses the comparative evaluation of the three different LWP waste treatment pathways in terms of their environmental and economic performance. Finally, the paper concludes with a summary of study implications and a discussion about its limitations and transferability to other contexts or subsequent studies.

\section{Study Context}

With its dual system, Germany has a structured source separation system in place where LWP waste is collected separately from other waste (i.e. residual municipal solid waste, paper/cardboard waste, glass bottles, etc.) in yellow containers and sacks ("Gelbe Tonne" and "Gelber Sack") [51]. The systems implementation was motivated by the enactment of 
the "Packaging Ordinance" in the early 1990s which anchored the "polluter pays principle" in Germany's waste management legislation [52]. Since then, companies that introduce LWPs to the market are obliged to contribute financially to their collection and recovery. Today, more than 2 million tonnes of LWP waste are collected annually by the dual system and are processed in MRFs [53].

The thorough separation of the individual packaging types in MRFs facilitates the production of homogeneous and high-quality material streams for recycling. However, the degree of separation depends on the efficiency of the sorting process. Inevitably, MRFs produce a residual fraction of materials (i.e. sorting residues) that are either too small for sorting or consist of multiple partially bonded materials that do not meet the quality standards for subsequent mechanical recycling processes [13]. According to the German Nature and Biodiversity Conservation Union (NABU), more than 50\% of LWP waste ends up as sorting residues which are not suitable for mechanical recycling [54]. Currently, these residues are typically processed as refuse-derived fuel (RDF) for energy and/or heat recovery in incineration facilities ranging from RDF power plants, cement works, to coal-fired power plants [51]. However, as sorting residues from LWP waste are carbon-rich, a potential alternative treatment pathway to incineration is the utilization of LWP sorting residues as secondary carbon feedstock for chemical production via CR.

Since the 1970s, a keen interest in CR development is evident from the deployment of a variety of experimental-, pilot-, and industrial-scale facilities in different countries [10, 55]. The term CR generally refers to the decomposition of carbonaceous waste either thermally or by solvents into synthesis gas monomers, oligomers, or higher hydrocarbons as products [10]. These products represent feedstocks for the production of plastics or other value products such as fertilizers, paints, or pharmaceuticals [8, 37, 56, 57]. According to Mamani et al. [10], CR technologies can be generally categorized in solvolysis, pyrolysis, and gasification [10]. However, not all CR technologies are suitable for processing LWP sorting residues with mixed compositions and low qualities. To date, only gasification technologies have been operated on an industrial-scale for such purpose. For example, in Berrenrath from 1993 to 1997 and in Schwarze Pumpe from 1995 to 2007 [40, 55, 58, 59], LWP sorting residues from the dual system served as co-feedstock with coal for syngas generation and subsequent methanol production in Germany. Another prominent example is Showa Denko K.K. in Kawasaki/Japan, where a plastic waste gasification plant has been in operation since 2003 to generate hydrogen for ammonia production [60].

In view of its previous and current practical application for the CR of plastic waste, this research evaluates gasification as the alternative CR treatment pathway to incineration pathways for LWP waste. Unlike incineration pathways where electricity and heat are the desired products, during the gasification process waste is broken down into a $\mathrm{CO}$ - and $\mathrm{H}_{2}$-rich syngas under high pressure and high temperature conditions with oxygen and/or steam as gasification agents. In subsequent downstream processes, syngas can be converted to platform chemicals such as methanol, which can then be further synthesized via a methanol-to-olefins process to olefins, an important intermediate raw material for the production of a broad spectrum of chemical products including virgin plastics [25, 61, 62].

Figure 1 illustrates the three LWP waste treatment pathways considered in this study. In Pathway I (i.e. reference scenario), LWP waste is channeled directly for incineration in RDF power plants without pre-sorting (i.e. no material recovery in MRF). Note that this does not reflect the case in Germany as LWP waste is pre-sorted in MRFs for mechanical recycling before sorting residues are sent as RDF for incineration (i.e. partial incineration). Nevertheless, in view that incineration is widely practiced and/ or considered for deployment in numerous EU countries (and worldwide), the direct 


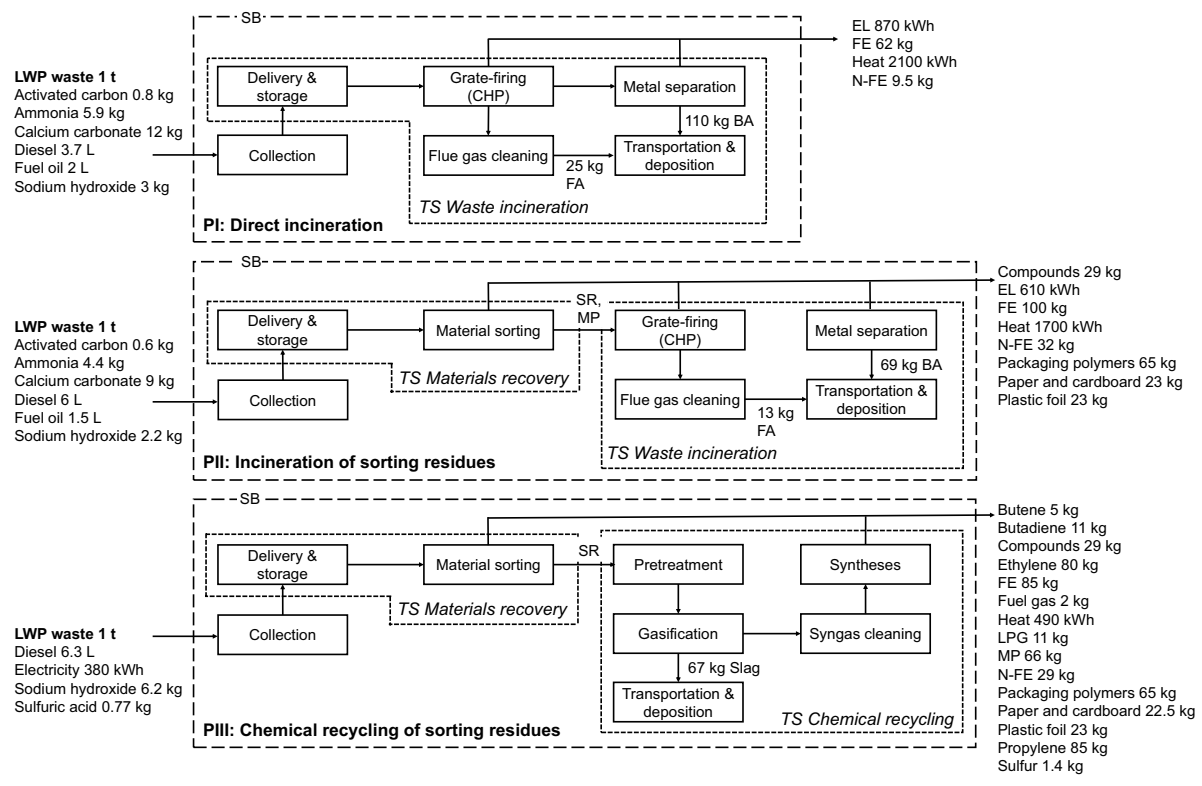

Fig. 1 System environment and results of inventory calculations. BA: Bottom ash. CHP: Combined heat and power generation. EL: Electricity. FA: Fly ash. FE: Ferrous scrap. LPG: Liquefied petroleum gas. LWP: Lightweight packaging. MP: Mixed plastics. N-FE: Non-ferrous scrap. SB: System boundaries. SR: Sorting residues. TS: Treatment step. Underlying values rounded to two significant digits. Energy figures are reported net of energy self-use

incineration pathway (PI) provides a theoretical basis of comparison to illustrate the environmental and economic impacts for recycling efforts of LWP waste via partial incineration in Pathway II (PII), as well as via CR in Pathway III (PIII).

\section{Methodology}

The assessment of the three LWP waste treatment pathways, i.e. incineration (PI), partial incineration (PII), and CR (PIII), builds on Voss et al. [46] and is conducted via three individual steps: First, a comprehensive inventory dataset for the treatment of LWP waste at three representative plant sites, reflecting PI to PIII, is generated (see the "Inventory Dataset" section). Second, based on the developed inventory dataset, an life cycle assessment of impacts along midpoint indicators climate change, terrestrial acidification, and fossil resource scarcity for the treatment of one tonne of LWP waste is conducted for each plant site (see the "Environmental Assessment" section). Third, techno-economic analyses of TCI, NPV, DPP, and LCCA are performed to evaluate economic plant site performances (see the "Techno-economic Analysis" section). 


\section{Inventory Dataset}

\section{Definition and Characterization of LWP Waste in Germany}

For the investigation, LWP waste is defined as waste material that is assigned to the waste code number EAV-15010601-U for "light weight packaging" in the disposal statistics by the German Federal Statistical Office [53]. Note that German authorities utilize EAV-15010601-U as a subgroup for the European waste code number EAV-150106 for "mixed packaging" [53, 63]. The assumed LWP waste composition as presented in Table S1 in the Supplementary Information (SI) relies on data from a study conducted by the German Environment Agency (UBA) [64]. Chemical composition of each subfraction is based on Riber et al. [65], resulting in chemical characteristics for LWP waste - e.g. water content, lower calorific value, and carbon content - as presented in Table S2 in the SI.

\section{Technological System}

Scientific publications, governmental technical reports, LCI databases, and process modeling results serve as data sources for the investigated treatment technologies. Specifically, data on waste collection and waste transportation is drawn from Larsen [66] and Olesen [67]. Data for waste incineration is obtained from technical reports by UBA [51, 68] and corresponding BAT-documents by the European Commission [69, 70]. Data on materials recovery is drawn from research by Cimpan et al. [13]. Finally, data on chemical recycling is obtained from chemical process modeling via ASPEN Plus V10 based on the approach by Keller et al. [23]. Detailed material flow assumptions are presented in the following paragraphs. Aggregated inputs and outputs for each treatment pathway are illustrated in Fig. 1.

Collection and transportation LWP waste collection is modeled assuming the combustion of 3.1 L diesel tonne ${ }^{-1}$ in a waste collection truck [66]. Transportation of waste treatment outputs such as bottom ash, fly ash, slag, and sorting products is modeled under the assumption of a Euro-5 semitrailer truck with a cargo volume of 10 tonnes travelling fully loaded, consuming $0.021 \mathrm{~L}$ diesel tonne $\mathrm{km}^{-1}$ [67].

Waste incineration Incineration of LWP waste and LWP waste sorting residues is based on RDF incineration in German RDF power plants as described by UBA [51, 68]. The process consists of four steps, namely 1) delivery and storage, 2) grate-firing, 3) flue gas cleaning, and 4) metal separation:

- Step 1: Delivery and storage of LWP waste after collection are modeled via the combustion of $0.5 \mathrm{~L}$ diesel tonne $\mathrm{e}^{-1}$ in a wheel loader that operates at $33 \%$ average load factor [71]. Note that waste incineration does not include delivery and storage in PII, as it describes the second treatment step after materials recovery (cf. Fig. 1).

- Step 2: Grate-firing consumes 2 L fuel oil tonne ${ }^{-1}$ input as auxiliary fuel [70] and cogenerates heat and electricity. Cogeneration efficiencies are set to $37 \%$ for heat and $15 \%$ for electricity relative to the lower heating value of the input [68]. Please note that assumed values correspond to net values i.e. after deduction of internal energy consumption. Excess heat and electricity are fed into a local heat grid and the 
German electricity grid, respectively, to substitute conventional energy. Bottom ash from grate-firing is processed in Step 4.

- Step 3: Gas treatment for airborne emissions resulting from grate-firing is assumed with a wet flue gas cleaning based on data provided by UBA [51] and EC [70]. Specifically, the system consists of a dry electrostatic precipitator, a two-stage water scrubber unit, a selective catalytic reforming unit, and a fly-flow adsorption. Supply consumption is set to $0.8 \mathrm{~kg}$ activated carbon, $5.9 \mathrm{~kg}$ ammonia, $12 \mathrm{~kg}$ calcium carbonate, and $3 \mathrm{~kg}$ sodium hydroxide tonne ${ }^{-1}$ input $[51,70]$.

- Step 4: A metal separation unit - comprising of two overbelt magnets, a bar sizer, an impact crusher, a flip-flop sieve, and an eddy current separator - with recovery efficiencies of $80 \%$ for ferrous and $19.5 \%$ for non-ferrous metals is assumed [72].

Process-specific air emission of treatment include $750 \mathrm{~g} \mathrm{NOx}\left(4.3 \mathrm{~g} \mathrm{~N}_{2} \mathrm{O}\right), 260 \mathrm{~g} \mathrm{CO}$, $150 \mathrm{~g} \mathrm{SO}_{2}$, and $2.5 \mathrm{~g} \mathrm{CH}_{4}$ tonne ${ }^{-1}$ input [73, 74]. Fossil $\mathrm{CO}_{2}$ emission are calculated based on the fossil carbon content of input in EASETECH (cf. "Life Cycle Assessment Model"). Solid emissions include fly ash and bottom ash which are treated as follows: Fly ash is assumed to be transported $700 \mathrm{~km}$ to a salt mine (cf. process "collection and transportation") where it is utilized as backfilling material consuming $1.8 \mathrm{~L}$ diesel and $28 \mathrm{kWh}$ electricity tonne ${ }^{-1}$ fly ash [75]. Remaining bottom ash after metal separation is transported $2 \mathrm{~km}$ to a landfill, modeled with the combustion of $1 \mathrm{~L}^{\text {diesel tonne }}{ }^{-1}$ in a $89 \mathrm{KW}$ drivable machine charged to $36 \%$ on average [76]. Note that transportation via truck is generally considered one-way due to the assumption of optimized logistics.

Materials recovery Materials recovery is modeled based on data provided by Cimpan et al. [13] for MRFs in Germany. Treatment consists of two treatment steps, namely 1) delivery and storage and 2) material sorting:

- Step 1: Delivery and storage include reception of LWP waste and a pre-conditioning in form of bag opening and size reduction consuming $0.84 \mathrm{~L}$ diesel and $4.1 \mathrm{kWh}$ electricity tonne ${ }^{-1}$ LWP waste input [13].

- Step 2: Material sorting consists of i) a conditioning step with sieving steps or ballistic separation, ii) a primary sorting step for first separation into material groups, iii) a refining step to increase material output quality i.a. via manual sorting, and iv) a product handling step to prepare products for downstream processors via e.g. balling [13]. Assumed sorting efficiencies are based on data provided by Cimpan et al. [13] and UBA [51] for materials recovery processes with extensive plastic sorting (cf. SI, Table S3). Supply consumption includes $1.4 \mathrm{~L}$ diesel and $87 \mathrm{kWh}$ electricity tonne ${ }^{-1}$ LWP waste input [13].

Material recovery products include i) recyclable materials, ii) sorting residues, and iii) mixed plastics. For i), recyclable materials such as packaging polymers, plastic foil, and metals are transported $20 \mathrm{~km}$ to a recycling facility [13]. For ii), sorting residues are transferred to the next treatment step i.e. waste incineration or CR assuming the combustion of $0.5 \mathrm{~L}$ diesel tonne ${ }^{-1}$ in a wheel loader that operates at $33 \%$ average load factor [71]. For iii), mixed plastics are assumed to be treated via incineration based on Cimpan et al. [13]. As PII includes a corresponding treatment step, mixed plastics are assumed to be handled together with sorting residues (cf. Fig. 1). As PIII does not include a corresponding treatment step, mixed plastics are transported $20 \mathrm{~km}$ to an external RDF power plant assuming 
environmental impacts based on process "waste incineration" (see above) and costs based on Cimpan et al. [13] as displayed in Table 1.

CR Based on Keller et al. [23] and Poganietz et al. [86], CR is modeled via four individual process steps: 1) pretreatment, 2) gasification, 3) gas treatment, and 4) syntheses:

- Step 1: Pretreatment includes shredding and compacting of sorting residues consuming $3.7 \mathrm{kWh}$ electricity tonne ${ }^{-1}$ input [86].

- Step 2: Gasification is assumed to be realized via fixed-bed gasification with liquid slag extraction (BGL type) [23].

- Step 3: Gas treatment of raw product syngas includes i) a water scrubbing unit, ii) a two-stage, adiabatic CO shift unit, iii) a selective acid gas removal unit, and iv) a threestage Claus plant [23].

- Step 4: Syntheses of purified and conditioned syngas to olefins is realized via i) a syngas-to-methanol synthesis, ii) a methanol-to-olefins synthesis, and iii) a olefins recov-

Table 1 Assumed values for global warming potential (GWP100), acidification potential (AP), fossil fuel potential (FFP), and prices for supplies and products. *: CHP selling price. EM: EASETEACH modeling. Underlying values rounded to two significant digits. All prices assumed for year 2021

\section{Per GWP100 AP [kg SO 2 eq.] FFP [kg oil eq.] Price $[€]$ Sources} [kg CO 2 eq.]

\begin{tabular}{lllllll}
\hline Supplies & & & & & & \\
Activated carbon & $\mathrm{kg}$ & 5.1 & 0.0078 & 2.4 & 2.4 & {$[77,78]$} \\
Ammonia & $\mathrm{kg}$ & 2.3 & 0.00084 & 0.94 & 0.3 & {$[77,78]$} \\
Calcium carbonate & $\mathrm{kg}$ & 0.064 & 0.00026 & 0.025 & 0.10 & {$[77,78]$} \\
Diesel & $\mathrm{kg}$ & 0.5 & 0.0012 & 1.1 & 0.52 & {$[77,78]$} \\
Fuel oil & $\mathrm{L}$ & 0.43 & 0.00097 & 1.2 & 0.58 & {$[77,78]$} \\
Sodium hydroxide & $\mathrm{kg}$ & 0.95 & 0.0014 & 0.36 & 1.1 & {$[77,78]$} \\
Products & & & & & & \\
Butadiene & $\mathrm{kg}$ & 1.5 & 0.0019 & 1.5 & 0.7 & {$[77,78]$} \\
Butene & $\mathrm{kg}$ & 1 & 0.0023 & 1.4 & 0.7 & {$[77,78]$} \\
Compounds & $\mathrm{kg}$ & 1.1 & 0.0026 & 0.6 & 0 & {$[13,77,79]$} \\
Ethylene & $\mathrm{kg}$ & 1.4 & 0.0027 & 1.6 & 1.02 & {$[77,80]$} \\
Ferrous scrap & $\mathrm{kg}$ & 1.9 & 0.0032 & 0.38 & 0.17 & {$[13,77]$} \\
Fuel gas & $\mathrm{kg}$ & 0.61 & 0.00048 & 1.3 & 0.43 & {$[77,78]$} \\
Heat & $\mathrm{kWh}$ & 0.26 & 0.00021 & 0.084 & $0.024 *$ & {$[77,81,82]$} \\
Liquefied petroleum gas & $\mathrm{kg}$ & 0.79 & 0.0018 & 1.3 & 0.47 & {$[77,78]$} \\
Mixed plastics & $\mathrm{kg}$ & 1.1 & -0.00032 & -0.38 & 0.017 & $\mathrm{EM},[13]$ \\
$\quad$ incineration & & & & & & \\
Non-ferrous scrap & $\mathrm{kg}$ & 5.3 & 0.014 & 1.8 & 0.41 & {$[13,77]$} \\
Packaging polymers & $\mathrm{kg}$ & 1.5 & 0.0027 & 1.5 & 0.12 & {$[13,77]$} \\
Paper and cardboard & $\mathrm{kg}$ & 0.69 & 0.002 & 0.28 & 0.05 & {$[13,77]$} \\
Plastic foil & $\mathrm{kg}$ & 1.5 & 0.0027 & 1.5 & 0.11 & {$[13,77]$} \\
Propylene & $\mathrm{kg}$ & 1.4 & 0.0027 & 1.6 & 0.95 & {$[77,80]$} \\
Sulfur & $\mathrm{kg}$ & 0.66 & 0.0014 & 0.79 & 0.11 & {$[77,78]$} \\
Supply and product & & & & & & \\
Electricity & $\mathrm{kWh}$ & 0.42 & 0.00035 & 0.11 & $0.081 *$ & {$[77,83-85]$} \\
\hline & & & & & &
\end{tabular}


ery stage [23]. For i) syngas-to-methanol synthesis, a single stage quasi-isothermal fixed bed reactor of the Lurgi type is assumed. For ii) methanol-to-olefins synthesis, assumed process configuration refers to the UOP HYDRO methanol-to-olefins process [23]. In iii) the olefins recovery stage, product gas obtained from methanol-to-olefins process is introduced to an olefin recovery process that includes a sodium hydroxide scrubber, a cryogenic separation unit, a three-stage refringent plant, and an adsorption $\&$ extractive distillation unit to recover butene and butadiene.

Note that data for treatment steps 2) gasification, 3) gas treatment, and 4) synthesis is produced with the chemical process modeling software ASPEN Plus V10 as presented by Keller et al. [23]. Aggregated supply consumption includes $280 \mathrm{kWh}$ electricity and $9.1 \mathrm{~kg}$ sodium hydroxide tonne ${ }^{-1}$ sorting residue input. Treatment products of the CR process are assumed with $4.2 \mathrm{~kg}$ butadiene, $1.9 \mathrm{~kg}$ butene, $0.76 \mathrm{~kg}$ fuel gas, $710 \mathrm{kWh}$ heat as process steam that can be used for versatile applications at the plant site and/or for export, $16 \mathrm{~kg}$ liquified petroleum gas, and $240 \mathrm{~kg}$ olefins (120 kg ethylene, $130 \mathrm{~kg}$ propylene) tonne $^{-1}$ sorting residue input. Airborne emissions are accounted for with $710 \mathrm{~kg}$ fossil $\mathrm{CO}_{2}, 0.042 \mathrm{~kg} \mathrm{CO}, 0.13 \mathrm{~kg} \mathrm{SO}_{2}$, and $0.1 \mathrm{~kg} \mathrm{NOx}$ tonne ${ }^{-1}$ sorting residue input. $99 \mathrm{~kg}$ slag tonne ${ }^{-1}$ sorting residue input are transported $2 \mathrm{~km}$ to an adjacent landfill where it is deposited, modeled with the combustion of $1 \mathrm{~L}$ diesel tonne ${ }^{-1}$ in a $89 \mathrm{KW}$ drivable machine charged to $36 \%$ on average [76].

\section{Environmental Assessment}

ISO standard 14,040:2006 which defines life cycle assessment requirements is utilized to assess the environmental life cycle impacts of all treatment pathways [87].

\section{Goal and Scope}

Goal is to facilitate a comparative assessment of environmental impacts associated with the three pathways for LWP waste treatment, namely direct incineration in a RDF power plant without pre-sorting, incineration of sorting residues from MRF, and CR of sorting residues from MRF. The functional unit is defined as the treatment of one metric tonne of LWP waste, with fractional composition and chemical characteristics further described in Tables S1 and S2 in the SI. The geographical scope is Germany and the temporal scope is set to 2021 until 2028 as assumptions regarding waste composition or technology efficiency are based on current knowledge [79].

\section{System Boundaries}

As illustrated in Fig. 1, system boundaries extend from the point of waste collection in households to treatment product distribution. Waste generation upstream impacts are excluded as a zero-burden approach is applied [79]. Nevertheless, upstream impacts associated with supply utilization and downstream impacts associated with treatment product distribution are included via system expansion with a background system (cf. Table 1). Corresponding environmental footprints for supplies are drawn directly from $\mathrm{GaBi}$ [77]. In contrast, footprints for treatment products are calculated based on data provided by Montejo et al. [79] for market product substitution ratios that reflect quality/material losses 
during recycling processes and reduced market acceptance. Specifically, ferrous and nonferrous scraps substitute primary steel and aluminum at substitution ratios of $87 \%$ and $79 \%$, respectively. Paper \& cardboard waste substitutes primary paper at a ratio of $82 \%$. Both packaging polymers and plastic foil substitute primary low-density polyethylene at a substitution ratio of $81 \%$. Compounds are assumed to contain $74 \%$ paper, $22 \%$ plastic foil, and $4 \%$ aluminum based on the material composition of beverage cartons [79]. Material loss during decomposition is set to $22 \%$. After decomposition, individual components substitute primary market products at ratios defined above. Eventually, chemical recycling products, electricity, and heat substitute market products at a ratio of $100 \%$ as conventional quality can be expected [46]. Footprints for supplies and market products are drawn from $\mathrm{GaBi}$ [77]. Note that all applied footprints refer to specific or market average values, indicating the attributional mode of this assessment. Moreover, environmental impacts associated with plant construction are beyond the scope of the current investigation.

\section{Life Cycle Assessment Model}

The software EASETEACH V3.1.7. [88] - well established for waste management research [89-91] - is applied for the environmental assessment. EASETECH is developed at the Department of Environmental Engineering, Technical University of Denmark (DTU), and focuses i.a. on a detailed consideration of fractional composition and chemical characteristics of waste. In EASETECH, LWP waste can be modeled by combining predefined subfractions such as standard packaging polymers, plastic foils, and paper waste. Based on the assumed composition, the software then determines key characteristics of LWP waste including energy content, carbon content, and water content (cf. SI, Table S2 for chemical characteristics). At the same time, it allows a realistic representation of sorting processes as individual sorting efficiencies can be assumed for different sub-fractions.

\section{Impact Assessment}

Keller et al. [23] identified midpoint indicators climate change, terrestrial acidification, and fossil resource scarcity as relevant impact categories for the examination of incineration and CR via gasification for alternative carbon carriers in Germany. Note that further life cycle impact categories used in holistic analyses such as marine eutrophication or land use are not analyzed in the current investigation. Regarding impact assessment methods, impact on climate change is determined per mechanism global warming potential for a period of 100 year (GWP100) in line with the Fifth Assessment Report (AR5) of IPCC [92]. Biogenic $\mathrm{CO}_{2}$ emissions are considered climate-neutral in the investigation. Impact on terrestrial acidification is determined per mechanism acidification potential (AP) and impact on fossil resource scarcity per mechanism fossil fuel potential (FFP) based on the ReCiPe2016 framework by Huijbregts et al. [93].

\section{Environmental Sensitivity Analysis}

As the German energy system is currently undergoing substantial transformations [94], different compositions for energy supply, i.e. energy provision scenarios (EPS), are examined in more detail. Via sensitivity analysis, using data provided by the European Commission [95] for electricity provision and by BDI [81] for heat provision, the influence of changes 
in energy mix on environmental impacts is determined. Specifically, three EPS scenarios are investigated:

- Scenario EPS-BASIC with current emission factors for heat and electricity supply $\left(0.26 \mathrm{~kg} \mathrm{CO}{ }_{2}\right.$ eq., $0.00021 \mathrm{~kg} \mathrm{SO} \mathrm{SO}_{2}$ eq. $0.084 \mathrm{~kg}$ oil eq. $\mathrm{kWh}^{-1}$ heat; $0.42 \mathrm{~kg} \mathrm{CO}_{2}$ eq., $0.00035 \mathrm{~kg} \mathrm{SO}_{2}$ eq., $0.11 \mathrm{~kg}$ oil eq. $\mathrm{kWh}^{-1}$ electricity),

- Scenario EPS-PRED for predominantly renewable energy supply $(0.17 \mathrm{~kg} \mathrm{CO}$ eq., $0.00015 \mathrm{~kg} \mathrm{SO}$ eq., $0.064 \mathrm{~kg}$ oil eq. $\mathrm{kWh}^{-1}$ heat; $0.18 \mathrm{~kg} \mathrm{CO}_{2}$ eq., $0.00019 \mathrm{~kg} \mathrm{SO}$ eq., $0.074 \mathrm{~kg}$ oil eq. $\mathrm{kWh}^{-1}$ electricity),

- Scenario EPS-CN for nearly climate neutral energy supply via wind power $(0.012 \mathrm{~kg}$ $\mathrm{CO}_{2}$ eq., $0.000024 \mathrm{~kg} \mathrm{SO}$ eq., $0.0033 \mathrm{~kg}$ oil eq. $\mathrm{kWh}^{-1}$ heat; $0.011 \mathrm{~kg} \mathrm{CO}$ eq., $0.000023 \mathrm{~kg} \mathrm{SO}_{2}$ eq., $0.00312 \mathrm{~kg}$ oil eq. $\mathrm{kWh}^{-1}$ electricity).

Please note that indirect effects of energy provision such as impacts on metal or chemical production processes are beyond the scope of the current investigation.

\section{Techno-economic Analysis}

For the techno-economic analysis, each LWP waste treatment pathway is represented with a corresponding treatment plant with an assumed capacity of 300,000 tonnes LWP waste year $^{-1}$ based on capacity data for modern waste treatment plants in Germany [68]. Widely utilized techno-economic analyses including TCI, NPV, DPP, and LCCA for these plants are performed based on approaches by Peters et al. [96], Sinnott and Towler [97], and Friedman et al. [98]. Note that 2021 is assumed as the investment base year.

\section{Total Capital Investment (TCI)}

TCI is defined as fixed capital investment (FCI: manufacturing and plant facilities capital) plus working capital (WC: capital required for plant operation) (cf. Eq. 1) as suggested by Peters et al. [96]. FCI is calculated based on a power factor applied to capacity ratio approach [96]. Specifically, FCI data for individual plant components (cf. SI, Table S4) is drawn from the literature. This is multiplied by the ratio of targeted capacity to reference capacity raised to the power of 0.7 to reflect economies-of-scale [96], and then multiplied by a temporal price index ratio to account for temporal price developments [96]. For temporal price indexing, the Chemical Engineering Plant Costs Index (CEPCI) is utilized and extrapolated to 2021 based on first order linear regression (cf. SI, Table S5). Investment data for individual plant components for waste incineration is drawn from UBA [51]. For materials recovery, investment data from Cimpan et al. [13] is utilized. For CR, data provided by Poganietz et al. [86] is referred to. Note that WC is estimated at $15 \%$ of the FCI as suggested by Peters et al. [96].

$$
T C I=F C I+W C=\left(\sum_{p c} F C I_{p c}\left(\frac{c a p}{c a p_{r p}}\right)^{\kappa^{i n v}}\left(\frac{\text { pindex }}{\text { pindex }_{r y}}\right)\right)(1+w c r)
$$

with

cap Capacity [t]

cap $_{r p} \quad$ Capacity of reference plant $[\mathrm{t}]$ 


$\begin{array}{ll}F C I & \text { Fixed capital investment }[€] \\ F C I_{p c} & \text { Fixed capital investment for plant component }[€] \\ p c & \text { Plant component index [-] } \\ \text { pindex } & \text { Price index in year of construction [-] } \\ \text { pindex }_{r y} & \text { Price index in reference year [-] } \\ \kappa^{\text {inv }} & \text { Scaling power factor [-] } \\ W C & \text { Working capital }[€] \\ w c r & \text { Working capital rate }[\%]\end{array}$

\section{Net Present Value (NPV)}

As presented in Eq. 2, NPV represents the sum of all discounted cash flows over the entire life of an investment reduced by the FCI in investment base year [96]. Referring to Bator et al. [99], a construction period of 3 years for all treatment plants is assumed. Plant operation thus starts in year 2024 and is assumed at 30 years with $90 \%$ plant availability for all treatment plants [100-102]. Considered cash flows during plant operation are based on Peters et al. [96] as presented with Eqs. 3 to 13. Prices for supplies and treatment products are based on data provided by UN Comtrade [78] and Cimpan et. al. [13] as presented in Table 1. Other relevant parameters for calculations such as discount rate, tax rates, and inflation rates are presented in Table 2. Labor requirements are assumed at 91,000 employee hours year ${ }^{-1}$ for PI, 200,000 for PII, and 180,000 for PIII based on personnel requirements in German plants [13, 86, 103, 104]. Note that a share of $15 \%$ of the employee hours is assumed to be skilled labor instead of unskilled labor [96, 105].

Table 2 General economic assumptions for treatment cost calculation. LWP: Lightweight packaging. All prices assumed for year 2021. Underlying values rounded to two significant digits

\begin{tabular}{llll}
\hline & Unit & Value & Source \\
\hline Administration percentage & $\%$ & 25 & {$[96]$} \\
$\mathrm{CO}_{2}$ certificate price & $€ / \mathrm{t}$ & 25 & {$[106]$} \\
$\mathrm{CO}_{2}$ certificate price inflation & $\%$ & 5 & {$[107]$} \\
Consumables percentage & $\%$ & 20 & {$[96]$} \\
Corporate income tax rate & $\%$ & 15 & {$[108]$} \\
Depreciation period (linear) & $\mathrm{a}$ & 10 & {$[109]$} \\
Discount rate & $\%$ & 8 & {$[100]$} \\
Insurance percentage & $\%$ & 1 & {$[96]$} \\
Labor cost inflation rate & $\%$ & 2.6 & {$[110]$} \\
Labor power factor & $\%$ & 0.25 & {$[96]$} \\
Local tax percentage & $\%$ & 2 & {$[96]$} \\
Maintenance \& repair percentage & $\%$ & 4 & {$[96]$} \\
Overhead percentage & $\%$ & 50 & {$[96]$} \\
Price inflation & $\%$ & 1.4 & {$[111]$} \\
LWP waste gate fee & $€ / \mathrm{t}$ & 140 & {$[13]$} \\
Skilled employee hour & $€ / \mathrm{h}$ & 80 & {$[112]$} \\
Supervision percentage & $\%$ & 15 & {$[96]$} \\
Transportation cost rate & $€ / \mathrm{km}$ & 0.07 & {$[51]$} \\
Unskilled employee hour & $€ / \mathrm{h}$ & 63 & {$[112]$} \\
\hline
\end{tabular}




$$
N P V=\sum_{n=1}^{t} \frac{\sum_{k=1}^{10} C F_{n, k}}{(1+i)^{n}}-F C I
$$

with

$C F_{n, k} \quad$ Annual cashflow [€]

FCI Fixed capital investment $[€]$

$i \quad$ Discount rate [\%]

$k \quad$ Cashflow index [-]

$N P V \quad$ Net present value [€]

$\mathrm{t} \quad$ Investment period [a]

$$
C F_{1}=F C I(\text { insur }+ \text { lTax })
$$

with

$C F_{1} \quad$ Local taxes and insurances [ $\left.€\right]$

FCI Fixed capital investment [€]

insur Insurance percentage [\%]

ITax Local taxes percentage [\%]

$$
C F_{2}=F C I \text { maint }(1+\text { consum })
$$

with

$\mathrm{CF}_{2} \quad$ Maintenance \& repair [€]

consum Consumables percentage [\%]

FCI Fixed capital investment [€]

maint Maintenance \& repair percentage [\%]

$$
\mathrm{CF}_{3}=\sum_{s} \text { requi }_{s} \text { price }_{s}
$$

with

$\mathrm{CF}_{3} \quad$ Supplies [€]

price $\quad$ Price for $s[€ / \mathrm{t}]$

requis Requirements $s[\mathrm{t}]$

$s \quad$ Supply [-]

$$
C F_{4}=(\text { sEmploy sRate }+ \text { usEmploy usRate })(1+\text { supervis })
$$

with

$\mathrm{CF}_{4} \quad$ Labor [€]

sEmploy Skilled employee hours [h]

sRate Hourly rate for skilled labor [€/h]

supervis Supervision percentage [\%]

usEmploy Unskilled employee hours [h]

usRate Hourly rate for unskilled labor [€/h] 


$$
\mathrm{CF}_{5}=\mathrm{CF}_{4} \text { overhd }
$$

with

$\mathrm{CF}_{4} \quad$ Labor costs [€].

$\mathrm{CF}_{5}$ Overhead [€].

overhd Overhead percentage [\%]

$$
C F_{6}=\frac{C F_{4} \text { admin }}{1+\text { supervis }}
$$

with

admin Administration percentage [\%]

$\mathrm{CF}_{4} \quad$ Labor costs [€]

$\mathrm{CF}_{6} \quad$ Administration costs [€]

supervis Supervision percentage [\%]

$$
C F_{7}=\sum_{e m} \text { outp }_{\text {em }} \text { costs }_{\text {em }}
$$

with

$\mathrm{CF}_{7} \quad$ Environmental expenses [ $€$ ]

costs $_{\text {em }}$ Price for handling/treatment of em [€/t]

em Emission/contaminant [-]

outp $_{\text {em }}$ Output of em [t]

$$
C F_{8}=\sum_{\text {sto }} \text { outp }_{\text {sto }} \text { dist }_{\text {sto }} \text { tRate }
$$

with

$C_{8} \quad$ Transportation costs [€]

dist $_{\text {sto }} \quad$ Transportation distance for sto $[\mathrm{km}]$

outp $_{\text {sto }} \quad$ Output of sto [t]

sto Solid treatment output [-]

tRate Transportation cost rate $[€ / \mathrm{km}]$

$$
C F_{9}=\sum_{\text {prod }} \text { outp }_{\text {prod }} \text { price }_{\text {prod }}
$$

with

$\mathrm{CF}_{9} \quad$ Product revenues from sold products [€]

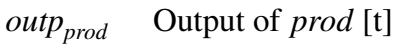

price $_{\text {prod }} \quad$ Selling price for $\operatorname{prod}[€ / \mathrm{t}]$

prod Product [-] 


$$
\begin{gathered}
\text { tinc }=\left(\sum_{k=1}^{9} C F_{k}-\text { depr }\right) \\
C F_{10}=\left\{\begin{array}{cc}
\text { tinc itax } & \text { tinc }>0 \\
0 & \text { tinc } \leq 0
\end{array}\right.
\end{gathered}
$$

with

$C F_{k} \quad$ Annual cashflow [€]

$C F_{10}$ Income tax rate $[€]$

depr Plant depreciation [€]

itax Corporate income tax rate [\%]

$k \quad$ Cashflow index [-]

tinc Taxable income $[€]$

\section{Dynamic Payback Period (DPP)}

As presented in Eq. 14, DPP represents the required time period to recover the initial FCI [113]. In other words, DPP refers to the first year of investment amortization. Note that DPP has integer values as cash flows are generally assumed to occur at the end of each year.

$$
\sum_{n=1}^{D P P} \frac{\sum_{k=1}^{10} C F_{n, k}}{(1+i)^{n}}-F C I=0
$$

with

$\begin{array}{ll}C F_{n, k} & \text { Annual cashflow }[€] \\ D P P & \text { Dynamic payback period [a] } \\ F C I & \text { Fixed capital investment [€] } \\ i & \text { Discount rate [\%] } \\ k & \text { Cashflow index [-] }\end{array}$

\section{Levelized Costs of Carbon Abatement (LCCA)}

As presented in Eq. 15, LCCA describes an investment on the basis of euros per tonne of reduced $\mathrm{CO}_{2}$ eq. [98]. For the calculation, the annual cost surpluses compared to the reference technology are divided by the annual $\mathrm{CO}_{2}$ eq. savings over the entire life of the investment. Note that PI is defined as the reference process for LCCA calculations for PII and PIII as it provides the theoretical basis to illustrate the environmental and economic impacts for recycling efforts of LWP waste in this study (cf. "Study Context" section). 


$$
L C C A=\sum_{n=1}^{t} \frac{\sum_{k=1}^{10} C F_{n, k}-C F R_{n, k}}{C A_{n}}
$$

with

$\begin{array}{ll}C A_{n, k} & \text { Annual carbon emission abatement }[\mathrm{t}] \\ C F_{n, k} & \text { Annual cashflow [€] } \\ C F R_{n, k} & \text { Annual reference cashflow [€] } \\ k & \text { Cashflow index [-] } \\ L C A A & \text { Levelized cost of carbon abatement }[€ / \mathrm{t}] \\ t & \text { Period of plant operation [a] }\end{array}$

\section{Economic Sensitivity Analysis}

Plant scaling, environmental regulation, and recycling product market conditions are analyzed via economic sensitivity analysis as they have been identified in previous studies to have the potential to affect the economic performance of the investigated treatment pathways [46]. Specifically, four economic scenarios (ES) are investigated:

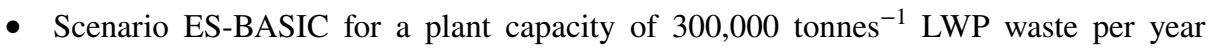
working at current market conditions and environmental regulations in Germany,

- Scenario ES-PS for plant scaling to 600,000 tonnes $^{-1}$ LWP waste per year $(+100 \%)$,

- Scenario ES-EREG for environmental regulation adjustment to exclude $\mathrm{CO}_{2}$ eq. emissions of CR from emission trading, i.e. no certificate costs for PIII, which is currently not the case [114],

- Scenario ES-MC for market condition adjustment to double attainable prices for CR products on the market compared to conventional products $(+100 \%)$.

\section{Results \& Discussion}

Figure 1 presents inventory results for the material inputs and outputs of all investigated treatment pathways. Results show that PI produces heat and electricity as central treatment outputs from LWP waste, while PII and PIII produce a variety of products for material recycling and/or versatile applications at chemical plant sites including plastic production. Results from environmental impact assessment are presented and discussed in the next section while results from the techno-economic analysis are presented in the "Economic Impacts" section. Note that additional results in the form of a fossil carbon balance and an energy balance are provided in Tables S6 \& S7 in the SI. 


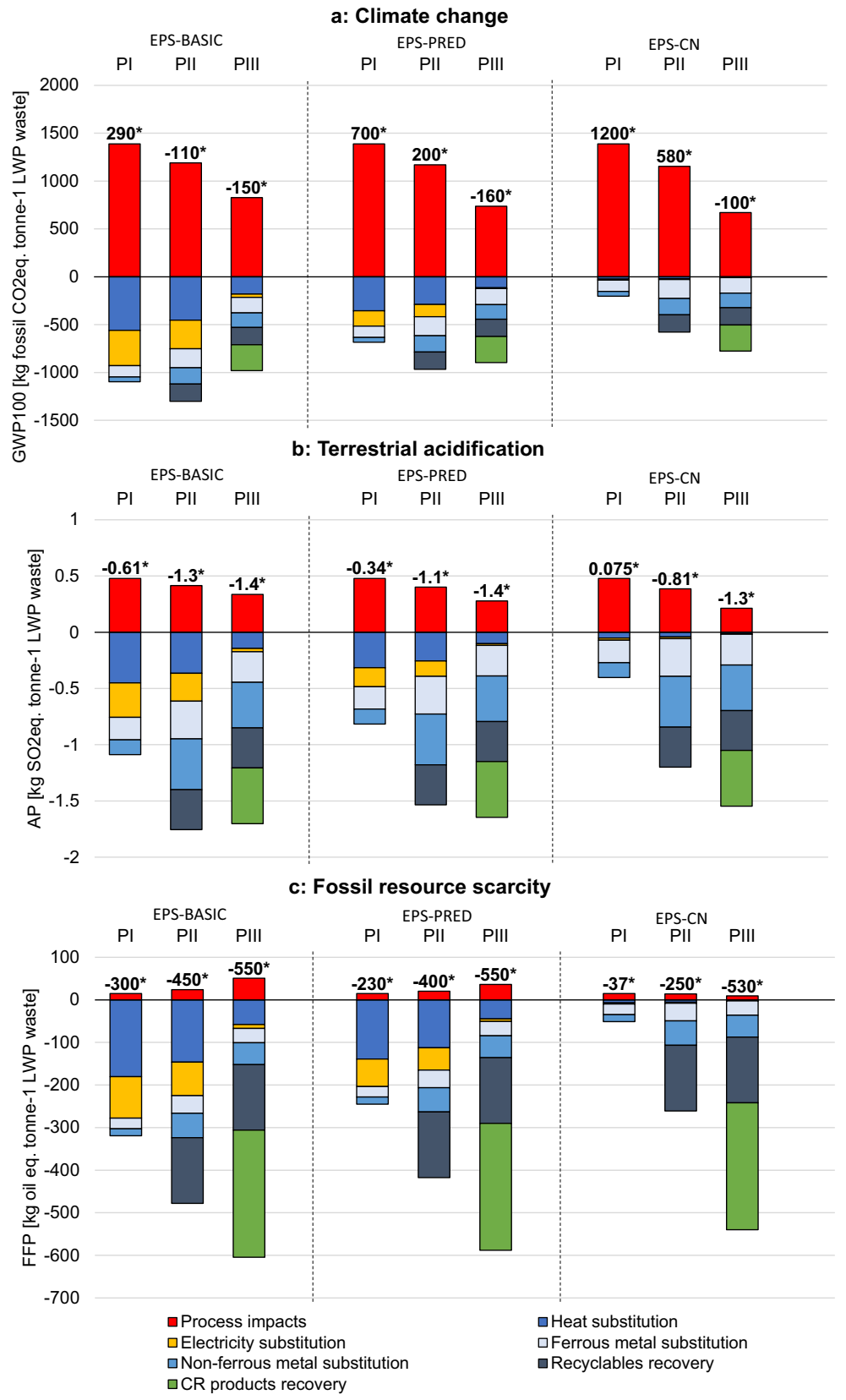

Fig. 2 Global warming potential, terrestrial acidification, and fossil resource scarcity results. AP: Acidification potential. CN: Climate neutrality. EPS: Energy provision scenario. FFP: Fossil fuel potential. GWP: Global warming potential. LWP: Lightweight packaging. PRED: Predominantly renewables. *: Resulting sum. Underlying values rounded to two significant digits 


\section{Environmental Impacts}

Figure $2 \mathrm{a}-\mathrm{c}$ present results from climate change, terrestrial acidification, and fossil resource scarcity assessments, respectively. For the analysis, impacts are divided into 1) process impacts, 2) heat substitution, 3) electricity substitution, 4) ferrous metal substitution, 5) nonferrous metal substitution, 6) recyclables recovery, and 7) CR products recovery. Results of the contribution analysis indicate that heat and electricity substitution have a major effect on the environmental viability of all impact categories. In the following paragraphs, results for the investigated scenarios will be discussed for each individual impact category.

\section{Climate Change}

In scenario EPS-BASIC, PI exhibits the highest GWP100 at $290 \mathrm{~kg} \mathrm{CO}_{2}$ eq tonne ${ }^{-1}$ LWP waste, whereas PII and PIII are associated with a GWP100 reduction at -110 and $-150 \mathrm{~kg}$ $\mathrm{CO}_{2}$ eq tonne ${ }^{-1}$ LWP waste, respectively. The high GWP100 reduction of PIII is due to low process emissions and chemical product substitution. In scenario EPS-PRED, assuming a predominant renewable energy supply, both PI and PII produce net positive $\mathrm{CO}_{2}$ eq. emissions at 700 and $200 \mathrm{~kg} \mathrm{CO}_{2}$ eq tonne ${ }^{-1}$ LWP waste, respectively, as emission credits for the substitution of electricity and heat are significantly reduced. In contrast, GWP100 reduction associated with PIII remains similar to that in scenario EPS-BASIC. In scenario EPS-CN with a climate neutral energy supply, while the GWP100 reduction effect of PIII is reduced by $50 \%$ to $-100 \mathrm{~kg} \mathrm{CO}_{2}$ eq tonne ${ }^{-1}$ LWP waste, the GWP100 of PI and PII will further increase to 1200 and $580 \mathrm{~kg} \mathrm{CO}_{2}$ eq tonne ${ }^{-1}$ LWP waste, respectively. Results thus strongly point to the GWP reduction potential of CR-based pathway PIII - irrespective of energy systems - in reducing carbon emissions associated with LWP waste treatment in comparison to incineration-based pathways PI and PII.

\section{Terrestrial Acidification}

Across all scenarios, PIII maintains a consistent contribution to reducing AP as a measure for the impact on terrestrial acidification at -1.4 to $-1.3 \mathrm{~kg} \mathrm{SO}_{2}$ eq. tonne ${ }^{-1} \mathrm{LWP}$ waste. This is because the lower credits for heat substitution in scenarios with increasing renewable energy supply are balanced with lower indirect $\mathrm{SO}_{2}$ eq. emissions that are induced by electricity consumption. In contrast, while incineration-based pathways also contribute to reducing AP, their contribution, in particularly for PI, is dependent on the energy supply in Germany. Hence, as process emissions and emission credits from electricity production become increasingly reduced corresponding to an increasing share of renewable energy supply, AP reduction also decreases considerably. In the case of PI, it reduces from -0.61 in Scenario BASIC to -0.34, and $0.075 \mathrm{~kg} \mathrm{SO}_{2}$ eq. tonne ${ }^{-1} \mathrm{LWP}$ waste. Taken together, while all treatment pathways contribute to a AP reduction, the contribution of CR pathway is largely independent of energy supply and remains consistent even assuming renewable energy supply. In contrast, the contribution of incineration-based pathways to AP reduction is dependent on the energy mix and exhibits a tendency to decrease as the share of renewables in the energy mix increases.

\section{Fossil Resource Scarcity}

Generally, all pathways contribute to a reduction in FFP as measure for the impact on fossil resource scarcity. For the incineration-based pathways PI and PII, this is primarily due to 


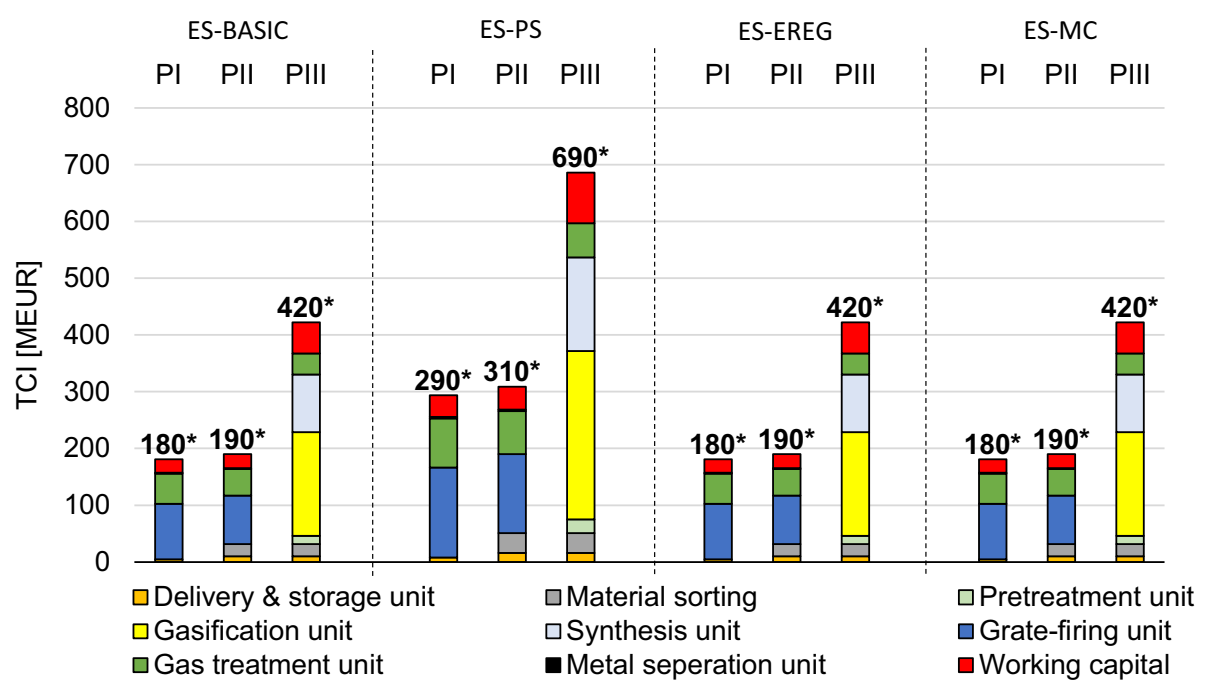

Fig. 3 Total capital investment (TCI). CN: Climate neutrality. EREG: Environmental regulation. ES: Economic scenario. MC: Market conditions. MEUR: Million euros. *: Resulting sum. Underlying values rounded to two significant digits

the substitution of conventional energy. In contrast, for the CR pathway PIII, this is due to the substitution of crude-oil-based olefins and by-products. Similar to climate change and terrestrial acidification, the contribution to decreasing fossil resource scarcity for PIII is observed to be relatively independent of the energy supply (i.e. remains consistent between -530 to $-550 \mathrm{~kg}$ oil eq. tonne ${ }^{-1}$ LWP waste). However, as with climate change and terrestrial acidification, the contributions of incineration-based pathways PI and PII are observed to be dependent on the energy mix and reduce significantly as the German energy supply becomes increasingly renewable.

\section{Economic Impacts}

\section{Total Capital Investment (TCI)}

Generally, PIII requires higher TCI than incineration-based pathways (see Fig. 3). Main drivers for TCI in PIII are investments in the gasification unit and the synthesis unit while grate-firing unit and the gas treatment unit represent the key TCI components of PI and PII. In scenario ES-BASIC, TCI for PIII is observed to be more than double that of PI and PII (i.e. 420 compared to 180 MEUR and 190 MEUR, respectively). Plant scaling is observed to have a significant impact on investments for all pathways. Specifically, for scenario ES-PS, an increase of about 60\% TCI (i.e. to 290, 310, and 690 MEUR for PI, PII, and PIII, respectively) is observed for a capacity increase of $100 \%$ for all pathways. The results are in line with reported investments for waste incineration plants [69], materials recovery facilities [13], and small scale gasification plants [115], and indicate that upscaling leads to significant economies-of-scale regardless of treatment pathways. No impact on TCI is observed for scenarios ES-EREG and ES-MC as assumptions for TCI are analog to scenario ES-BASIC. 

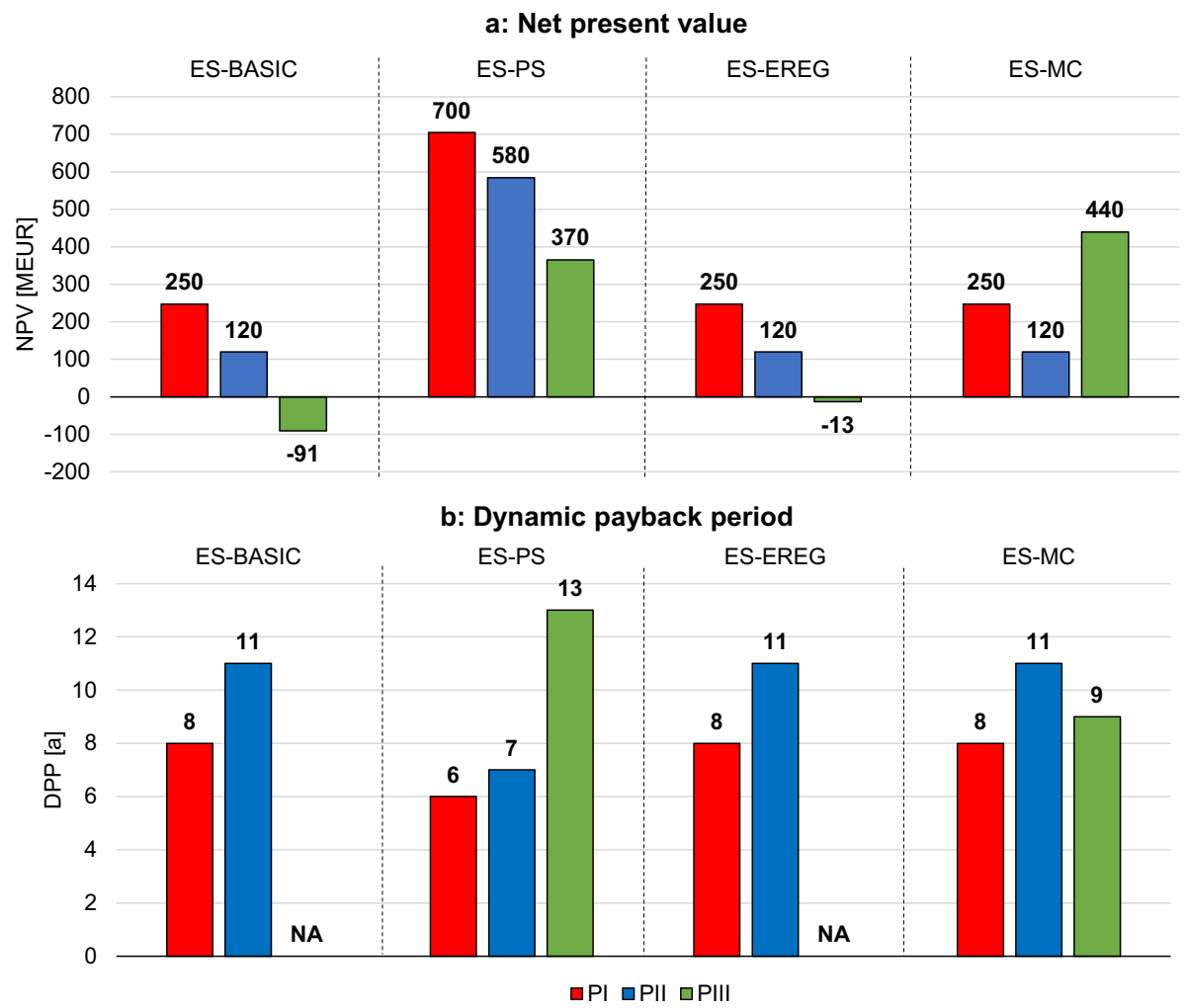

Fig. 4 Net present value (NPV) and dynamic payback period (DPP). CN: Climate neutrality. EREG: Environmental regulation. ES: Economic scenario. MC: Market conditions. MEUR: Million euros. NA: Not applicable. PS: Plant scaling. Underlying values rounded to two significant digits

\section{Net Present Value (NPV)}

In scenario ES-BASIC, NPV is highest for PI at 250 MEUR, followed by PII at 120 MEUR and PIII at -91 MEUR (see Fig. 4a). This indicates that PI and PII are profitable while PIII incurs financial losses. Upscaling is observed to have a significant positive impact on profitability for all pathways. When plant capacity is doubled to 600,000 tonnes LWP waste year $^{-1}$, PIII will exhibit a positive economic return (i.e. 370 MEUR). However, incineration-based pathways will also experience increased profitability at almost double that of the CR pathway (i.e. 700 and 580 MEUR for PI and PII, respectively). While environmental regulation (i.e. $\mathrm{CO}_{2}$ certificate costs waived for $\mathrm{CR}$ ) reduces the losses associated with PIII (i.e. from -91 MEUR in scenario ES-BASIC to -13 MEUR), it does not reach higher economic attractiveness than incineration-based pathways. The largest impact on the economic viability of PIII compared to incineration-based pathways is the realization of a price premium for CR products. In scenario ES-MC where market prices for CR products are assumed to be double that of conventional chemicals, CR pathway PIII - at 440 MEUR - will be much more profitable than incineration-based pathways (i.e. 250 and 120 for PI and PII, respectively). 


\section{Dynamic Payback Period (DPP)}

As illustrated in Fig. 4b, DPP is only relevant for pathways with positive NPV (i.e. investment will be repaid within the investment timeline). Under scenario ES-BASIC, direct incineration with a DPP of 8 years exhibits a better project feasibility than indirect incineration with a DPP of 11 years. With upscaling of plant capacity, the project attractivity of incineration-based pathways improves with a reduced DPP of 6 years. In contrast, the CR pathway will not be as economically attractive as incineration-based pathways in terms of DPP as it requires twice as long for the investment to be repaid. Nevertheless, even with the longer DPP, the investment will be paid back in less than half of the investment lifespan of the CR plant (i.e. at 33 years). Not surprisingly, environmental regulation relating to $\mathrm{CO}_{2}$ certificate costs for $\mathrm{CR}$ is observed to have no impact on DPP for incineration-based pathways compared to scenario ES-BASIC. Assuming a price premium for CR products, a similar DPP for PIII (i.e. 9 years) and PII (i.e. 8 years) is observed.

\section{Levelized Costs of Carbon Abatement (LCCA)}

LCCA is calculated for PII and PIII using PI as the reference pathway. The energy mix is observed to exert a significant impact on carbon emissions for LWP waste treatment pathways (see the "Climate Change" section). This will have a corresponding impact on LCCA. The difference in energy mixes is thus accounted for in the LCCA via the energy scenarios EPS-BASIC, EPS-PRED, and EPS-CN.

Not surprisingly, for all economic scenarios (i.e. ES-BASIC, ES-PS, ES-EREG, and ES-MC), LCCA for both indirect incineration (i.e. PII) and CR (i.e. PIII) - compared to PI as reference pathway - will decrease as the proportion of renewables in the energy mix increases (see Fig. 5). Interestingly, under existing market conditions i.e. ES-BASIC, while PII will incur lower LCCA compared to PIII under EPS-BASIC condition (i.e. 130 compared to $180 €$ tonne ${ }^{-1} \mathrm{CO}_{2}$ eq.), this tendency is reversed as the proportion of renewables in the energy mix increases. Specifically, PIII incurs less LCCA compared to PII in EPS-PRED and EPS-CN at 93 and $62 €$ tonne $^{-1} \mathrm{CO}_{2}$ eq. compared to 110 and $89 €$ tonne ${ }^{-1} \mathrm{CO}_{2}$ eq., respectively. This indicates that with increasing renewables in the energy mix, the attractivity of CR compared to indirect incineration (i.e. in terms of reduced LCCA) will correspondingly increase.

For PII, the only economic scenario which has an impact in reducing its LCCA is ES-PS. For PIII, not only do plant scaling (ES-PS) and a waiver of $\mathrm{CO}_{2}$ certificate costs for CR (ES-EREG) lead to a significant reduction of LCCA; in the case of a price premium for CR products (ES-MC), negative LCCA values indicate that carbon saving and cost reduction can be attained at the same time.

Taken together, assuming an increasing proportion of renewable energy supply in the future as economies strive for carbon neutrality and net-zero, CR will present an economically attractive alternative to indirect incineration to abate carbon emissions across diverse economic scenarios.

\section{Conclusion}

This study quantitatively evaluates the environmental and economic impacts associated with gasification as an alternative chemical recycling treatment pathway to direct and indirect incineration pathways for lightweight packaging waste. To support the comparative 


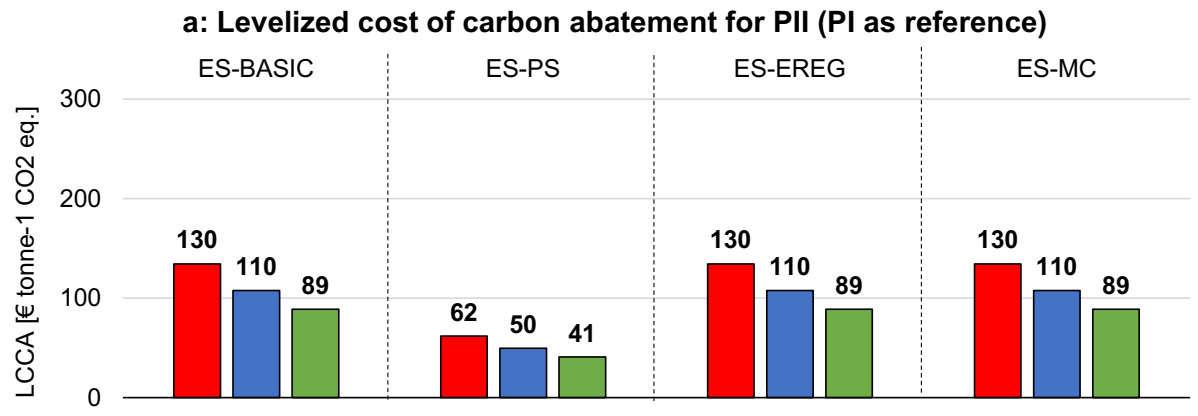

b: Levelized cost of carbon abatement for PIII (PI as reference)

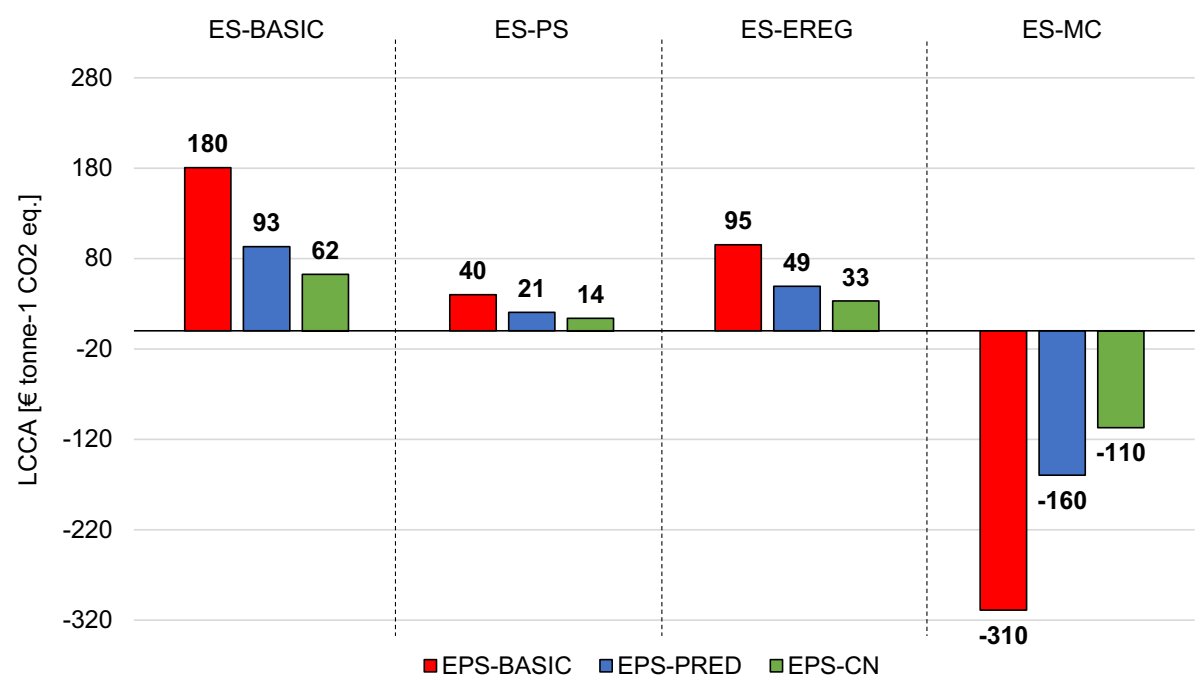

Fig. 5 Levelized cost of carbon abatement (LCCA). CN: Climate neutrality. EPS: Energy provision scenario. ES: Economic scenario. EREG: Environmental regulation. MC: Market conditions. PRED: Predominantly renewable energy supply. PS: Plant scaling. Underlying values rounded to two significant digits

life cycle assessment and techno-economic analyses, a comprehensive inventory dataset is developed to enable in-depth assessments of material flows, environmental impacts, and economic performance of conventional and innovative treatment pathways for lightweight packaging waste. This study provides novel insights into environmental impacts which are associated with the investigated treatment pathways in terms of climate change, terrestrial acidification, and fossil resource scarcity, as well as their sensitivity to changes in the energy system. Additionally, it also enables an empirical overview of associated economic impacts in terms of total capital investment, net present value, dynamic payback period, and levelized cost of carbon abatement, as well as their sensitivity to changes in economic conditions in terms of plant scaling, changes in environmental regulations (i.e. wavier of $\mathrm{CO}_{2}$ prices for chemical recycling), as well as market conditions (i.e. price premium for CR products).

Study results indicate that chemical recycling of sorting residues of lightweight packaging waste in the form of gasification has a significant positive environmental potential 
which is currently unexploited. Unlike incineration-based pathways whose environmental impacts are dependent on emission credits they receive for substitution of electricity and heat, the contribution of chemical recycling to reducing impacts on climate change, terrestrial acidification, and fossil resource scarcity are shown to be relatively independent of the energy mix. Results thus suggest that as economies transform their energy systems towards renewable energy, the environmental contribution of incineration-based treatment of lightweight packaging waste will decrease considerably, whereas that of chemical recycling will remain relatively stable.

From an economic standpoint, the high total capital investment of chemical recycling compared to incineration-based pathways may limit its economic attractiveness for investors. However, results also point to how a multi-pronged approach which integrates generous plant scaling with favorable environmental regulation for chemical recycling and a price premium for chemical recycling products could significantly increase its economic competitiveness such that chemical recycling is comparable, and even more profitable under certain conditions to incineration-based pathways.

To conclude, this research extends the isolated focus of extant chemical recycling studies on technical issues to assess environmental and economic impacts which are associated with the implementation of chemical recycling in the form of waste gasification in comparison to incineration-based treatment pathways. The integrated approach utilized is conducted in line with proven practices of life cycle assessment and techno-economic analysis, and accounts for both upstream and downstream impacts of plastic waste treatment. Key advantages of the applied methods include a detailed and reliable inventory dataset as well as inferences for the realization of chemical recycling in the form of gasification at plant level.

Despite the novel insights which are obtainable through this approach, a central limitation is the limited transferability of attained results to a large-scale, systemic implementation of chemical recycling. Moreover, the focus on Germany also limits the direct transferability of study findings to other nations and contexts. Future research could thus benefit from an integration of data and results from this study with sophisticated systemic modeling approaches, and a consideration of the role of chemical recycling in diverse and wider economies (e.g. in the European Union). Such a systemic approach could lead to a deeper understanding of how chemical recycling could complement other strategies in the complex and interconnected systems of waste treatment, chemical production, and energy provision - including the associated infrastructural, regulatory, and financial dynamics - to address the global plastic waste challenge.

Notwithstanding the identified limitations of the present study and the potential avenues for future research, this study provides a comprehensive assessment of environmental and economic impacts associated with chemical recycling compared to established incineration-based treatment pathways for lightweight packaging waste. It thus contributes to research and development in this field by providing empirical evidence of environmental benefits of chemical recycling as well as economic data on required investments and economic performance. Study results strongly suggest that chemical recycling could play a role as a complementary building block to mechanical recycling to close material cycles in circular economies. It furthermore provides decision-makers with insights into the framework conditions which would be necessary to enable the realization of chemical recycling's potential in addressing the plastic waste challenge.

Supplementary Information The online version contains supplementary material available at https://doi. org/10.1007/s43615-021-00145-7. 
Author Contribution Conceptualization: Raoul Voss, Roh Pin Lee, Magnus Fröhling; Methodology: Raoul Voss, Magnus Fröhling; Formal analysis and investigation: Raoul Voss; Writing —original draft preparation: Raoul Voss; Writing — review and editing: Raoul Voss, Roh Pin Lee, Magnus Fröhling; Funding acquisition: Roh Pin Lee; Supervision: Roh Pin Lee, Magnus Fröhling.

Funding Open Access funding enabled and organized by Projekt DEAL. This research received funding from the German Federal Ministry of Education and Research (BMBF) under the Grant Agreement No. 01LN1713A. All opinions, results and conclusions in the text are those of the authors and do not necessarily reflect the opinion of the BMBF.

Data Availability Not applicable.

Code Availability Not applicable.

\section{Declarations}

Conflict of Interest The authors declare no competing interests.

Open Access This article is licensed under a Creative Commons Attribution 4.0 International License, which permits use, sharing, adaptation, distribution and reproduction in any medium or format, as long as you give appropriate credit to the original author(s) and the source, provide a link to the Creative Commons licence, and indicate if changes were made. The images or other third party material in this article are included in the article's Creative Commons licence, unless indicated otherwise in a credit line to the material. If material is not included in the article's Creative Commons licence and your intended use is not permitted by statutory regulation or exceeds the permitted use, you will need to obtain permission directly from the copyright holder. To view a copy of this licence, visit http://creativecommons.org/licenses/by/4.0/.

\section{References}

1. Lee RP, Scheibe A (2020) The politics of a carbon transition: An analysis of political indicators for a transformation in the German chemical industry. J Clean Prod 244:118629. https://doi.org/10.1016/j. jclepro.2019.118629

2. Worrell E (ed) (2014) Handbook of Recycling. Elsevier Science Publishing Co Inc, Amsterdam ISBN: 9780123964595

3. Barnes DKA, Galgani F, Thompson RC et al (2009) Accumulation and fragmentation of plastic debris in global environments. Philos Trans R Soc Lond B Biol Sci 364:1985-1998. https://doi.org/ 10.1098/rstb.2008.0205

4. van Cauwenberghe L, Vanreusel A, Mees J et al (2013) Microplastic pollution in deep-sea sediments. Environ Pollut 182:495-499. https://doi.org/10.1016/j.envpol.2013.08.013

5. Tanaka K, Takada H (2016) Microplastic fragments and microbeads in digestive tracts of planktivorous fish from urban coastal waters. Sci Rep 6:34351. https://doi.org/10.1038/srep34351

6. EC (2020) EU Circular Economy Action Plan - A new Circular Economy Action Plan for a Cleaner and More Competitive Europe. https://ec.europa.eu/environment/circular-economy/. Accessed $27 \mathrm{Jul}$ 2021

7. EC (2020) Summary of Directive 94/62/EC on packaging and packaging waste. https://eur-lex. europa.eu/legal-content/EN/TXT/?qid=1595838206165\&uri=LEGISSUM:121207. Accessed $27 \mathrm{Jul}$ 2021

8. BASF (2020) Chemical recycling of plastic waste. https://www.basf.com/global/en/who-we-are/susta inability/we-drive-sustainable-solutions/circular-economy/mass-balance-approach/chemcycling.html. Accessed 27 Jul 2021

9. Ragaert K, Delva L, van Geem K (2017) Mechanical and chemical recycling of solid plastic waste. Waste Manage 69:24-58. https://doi.org/10.1016/j.wasman.2017.07.044

10. Mamani P, Seidl LG, Keller F et al (2020) Chemisches Recycling - Aktueller Stand und neue Entwicklungen. In: Thomé-Kozmiensky E, Holm O, Friedrich B et al (eds) Recycling and secondary raw materials - 13. Thomé-Kozmiensky Verlag GmbH, Nietwerder, pp 268-284 ISBN: 9783944310510 
11. Rahimi A, García JM (2017) Chemical recycling of waste plastics for new materials production. Nat Rev Chem 1:409. https://doi.org/10.1038/s41570-017-0046

12. Lee RP, Tschoepe M, Voss R (2021) Perception of chemical recycling and its role in the transition towards a circular carbon economy: A case study in Germany. Waste Manag 125:280-292. https://doi. org/10.1016/j.wasman.2021.02.041

13. Cimpan C, Maul A, Wenzel H et al (2016) Techno-economic assessment of central sorting at material recovery facilities - the case of lightweight packaging waste. J Clean Prod 112:4387-4397. https:// doi.org/10.1016/j.jclepro.2015.09.011

14. EC (2018) Changing the way we use plastics. Publications Office of the Europea Union, Luxembourg ISBN: 978927977515-4

15. EC (2013) Plastic Waste in the Environment - Revised final report. https://op.europa.eu/en/publication-detail/-/publication/fd4f120a-bf98-403b-a22e-ca4d7b280da8. Accessed 27 Jul 2021

16. PlasticsEurope (2019) Plastics - the Facts. https://www.plasticseurope.org/application/files/9715/ 7129/9584/FINAL_web_version_Plastics_the_facts2019_14102019.pdf. Accessed 27 Jul 2021

17. EUROSTAT (2020) Packaging waste by waste management operations and waste flow (Code: env_ waspac). https://ec.europa.eu. Accessed 27 Jul 2021

18. Nabavi-Pelesaraei A, Bayat R, Hosseinzadeh-Bandbafha $\mathrm{H}$ et al (2017) Modeling of energy consumption and environmental life cycle assessment for incineration and landfill systems of municipal solid waste management - A case study in Tehran Metropolis of Iran. J Clean Prod 148:427-440. https:// doi.org/10.1016/j.jclepro.2017.01.172

19. Lee RP, Meyer B, Huang Q et al (2020) Sustainable waste management for zero waste cities in China: potential, challenges and opportunities. Clean Energy 4:169-201. https://doi.org/10.1093/ce/zkaa013

20. Jeswani HK, Smith RW, Azapagic A (2013) Energy from waste: carbon footprint of incineration and landfill biogas in the UK. Int J Life Cycle Assess 18:218-229. https://doi.org/10.1007/ s11367-012-0441-8

21. Rabl A, Spadaro JV, Zoughaib A (2008) Environmental impacts and costs of solid waste: a comparison of landfill and incineration. Waste Manag Res 26:147-162. https://doi.org/10.1177/0734242X07 080755

22. Guo H, Duan Z, Zhao Y et al (2017) Characteristics of volatile compound emission and odor pollution from municipal solid waste treating/disposal facilities of a city in Eastern China. Environ Sci Pollut Res Int 24:18383-18391. https://doi.org/10.1007/s11356-017-9376-8

23. Keller F, Lee RP, Meyer B (2020) Life cycle assessment of global warming potential, resource depletion and acidification potential of fossil, renewable and secondary feedstock for olefin production in Germany. J Clean Prod 250:119484. https://doi.org/10.1016/j.jclepro.2019.119484

24. Lee RP (2019) Alternative carbon feedstock for the chemical industry? - Assessing the challenges posed by the human dimension in the carbon transition. J Clean Prod 219:786-796. https://doi.org/10. 1016/j.jclepro.2019.01.316

25. Lee RP, Keller F, Meyer B (2018) A concept to support the transformation from a linear to circular carbon economy: net zero emissions, resource efficiency and conservation through a coupling of the energy, chemical and waste management sectors. Clean Energy 1:102-113. https://doi.org/10.1093/ ce/zkx004

26. European Bioplastics e.V. (2015) Factsheet April 2015 - Mechanical Recycling. https://docs.europ ean-bioplastics.org/publications/bp/EUBP_BP_Mechanical_recycling.pdf. Accessed 27 Jul 2021

27. Nikolaou IE, Jones N, Stefanakis A (2021) Circular Economy and Sustainability: the Past, the Present and the Future Directions. Circ Econ Sust 1:1-20. https://doi.org/10.1007/s43615-021-00030-3

28. Lee RP, Reinhardt R, Keller F et al (2018) A raw materials transition for a low-carbon economy: challenges and opportunities for management in addressing the trilemma of competitiveness, supply security and sustainability. In: George G, Schillebeeckx S (eds) Managing Natural Resources. Edward Elgar Publishing. ISBN: 9781786435729. pp 61-87

29. Seidl LG, Lee RP, Keller F et al (2020) Beitrag des chemischen Recyclings zur Defossilierung von Rohstoffketten - Konzeptstudie für die nachhaltige Olefinerzeugung in Deutschland. In: Thiel S, Thomé-Kozmiensky E, Quicker PQ et al (eds) Energy from waste - 17. Thomé-Kozmiensky Verlag GmbH, Nietwerder. ISBN: 9783944310503

30. The Green Dot (2020) About us. https://www.gruener-punkt.de/en/company/about-us.html. Accessed 27 Jul 2021

31. Fishbein BK (1994) Germany, garbage, and the green dot: Challenging the throwaway society. Inform, United States. ISBN: 9780918780614

32. Conversio (2020) Studie Stoffstrombild Kunststoffe in Deutschland 2017. https://issuu.com/plast icseuropeebook/docs/kurzfassung_stoffstrombild_kunststoffe_2019?e=14847134/80757890. Accessed 27 Jul 2021 
33. INEOS (2020) Styrolution: Breakthrough in chemical recycling of polystyrene. https://www. ineos-styrolution.com/news/ineos-styrolution-breakthrough-in-chemical-recycling-of-polystyrene. Accessed 27 Jul 2021

34. LB (2020) LyondellBasell advances chemical recycling by signing agreement with the Karlsruhe Institute of Technology. https://www.lyondellbasell.com/en/news-events/products--technologynews/lyondellbasell-advances-chemical-recycling-by-signing-agreement-with-the-karlsruhe-insti tute-of-technology/. Accessed 27 Jul 2021

35. ZWE (2019) El Dorado of Chemical Recycling - State of play and policy challenges. https://circu lareconomy.europa.eu/platform/sites/default/files/2019_08_29_zwe_study_chemical_recycling. pdf. Accessed 27 Jul 2021

36. PRE (2020) Chemical recycling. https://www.plasticsrecyclers.eu/chemical-recycling. Accessed 27 Jul 2021

37. ACC (2020) Plastics - What is advanced recycling? https://plastics.americanchemistry.com/Advan ced-Recycling-101/. Accessed 27 Jul 2021

38. Dumée LF (2021) Circular Materials and Circular Design-Review on Challenges Towards Sustainable Manufacturing and Recycling. Circ Econ Sust. https://doi.org/10.1007/ s43615-021-00085-2

39. Debnath B, Ghosh S, Dutta N (2021) Resource Resurgence from COVID-19 Waste via Pyrolysis: a Circular Economy Approach. Circ Econ Sust. https://doi.org/10.1007/s43615-021-00104-2

40. Lee RP, Seidl L, Huang Q et al (2021) An analysis of waste gasification and its contribution to China's transition towards carbon neutrality and zero waste cities. J Fuel Chem Technol 49:10571076. https://doi.org/10.1016/S1872-5813(21)60093-2

41. Solis M, Silveira S (2020) Technologies for chemical recycling of household plastics - A technical review and TRL assessment. Waste Manage 105:128-138. https://doi.org/10.1016/j.wasman.2020. 01.038

42. Wei T-T, Wu K-J, Lee S-L et al (2010) Chemical recycling of post-consumer polymer waste over fluidizing cracking catalysts for producing chemicals and hydrocarbon fuels. Resour Conserv Recycl 54:952-961. https://doi.org/10.1016/j.resconrec.2010.02.002

43. Zeller M, Netsch N, Richter F et al (2021) Chemical Recycling of Mixed Plastic Wastes by Pyrolysis - Pilot Scale Investigations. Chem Ing Tec. https://doi.org/10.1002/cite.202100102

44. Maga D, Hiebel M, Thonemann N (2019) Life cycle assessment of recycling options for polylactic acid. Resour Conserv Recycl 149:86-96. https://doi.org/10.1016/j.resconrec.2019.05.018

45. Shen L, Worrell E, Patel MK (2010) Open-loop recycling: A LCA case study of PET bottle-tofibre recycling. Resour Conserv Recycl 55:34-52. https://doi.org/10.1016/j.resconrec.2010.06.014

46. Voss R, Lee RP, Seidl L et al (2021) Global warming potential and economic performance of gasification-based chemical recycling and incineration pathways for residual municipal solid waste treatment in Germany. Waste Manage 134:206-219. https://doi.org/10.1016/j.wasman.2021.07.040

47. Ren T, Patel M, Blok K (2006) Olefins from conventional and heavy feedstocks: Energy use in steam cracking and alternative processes. Energy 31:425-451. https://doi.org/10.1016/j.energy.2005.04.001

48. Mastellone ML (2019) A feasibility assessment of an integrated plastic waste system adopting mechanical and thermochemical conversion processes. Resour, Conserv Recycl: X 4:100017. https://doi.org/10.1016/j.rcrx.2019.100017

49. Rollinson A, Oladejo J (2020) Chemical Recycling: Status, Sustainability, and Environmental Impacts. https://www.no-burn.org/wp-content/uploads/CR-Technical-Assessment_June-2020.pdf. Accessed 27 Jul 2021

50. Nabavi-Pelesaraei A, Rafiee S, Mostahari-Rad F et al Life Cycle Assessment (LCA) Approach to Evaluate Different Waste Management Opportunities. In: Advances in Waste-to-Energy Technologies. CRC Press. pp 195-216

51. UBA (2018) Best practices in municipal waste management. https://www.umweltbundesamt.de/publi kationen/best-practice-municipal-waste-management. ISSN: 18624804. Accessed 27 Jul 2021

52. German Federal Government (2017) Verordnung über die Vermeidung und Verwertung von Verpackungsabfällen (VerpackV). https://www.bmu.de/gesetz/verordnung-ueber-die-vermeidungund-verwertung-von-verpackungsabfaellen/. Accessed 27 Jul 2021

53. DESTATIS (2019) Umwelt - Abfallentsorgung. https://www.destatis.de/DE/Themen/Gesellscha ft-Umwelt/Umwelt/Abfallwirtschaft/Publikationen/Downloads-Abfallwirtschaft/abfallentsorgung2190100177004.pdf?_blob=publicationFile. Accessed 27 Jul 2021

54. NABU (2020) Recycling und der Gelbe Sack: It's complicated! https://www.nabu.de/umwelt-undressourcen/abfall-und-recycling/recycling/21113.html. Accessed 27 Jul 2021

55. Schmalfeld J, Arendt P (eds) (2008) The refinement and conversion of coal - technologies and projects 1970 to 2000 in Germany, Hamburg. ISBN: 9783936418880 
56. NABU (2020) Chemisches Recycling von Kunststoffen. https://www.nabu.de/umwelt-und-resso urcen/abfall-und-recycling/recycling/27543.html. Accessed 27 Jul 2021

57. Neste (2019) Neste and Ravago start collaboration to enable chemical recycling. https://www.neste. $\mathrm{com} /$ releases-and-news/circular-economy/neste-and-ravago-start-collaboration-enable-chemicalrecycling-over-200000-tons-plastic-waste. Accessed 27 Jul 2021

58. Lee RP, Laugwitz A, Keller F et al (2017) Achieving a closed carbon \& circular economy for the waste management sector - net zero emissions, resource efficiency and conservation by coupling the energy, chemical and recycling sectors. In: Thomé-Kozmiensky KJ, Thiel S, Thomé-Kozmiensky E et al (eds) Waste management - 7. TK-Verl., Neuruppin. ISBN: 3944310373

59. Lee RP, Wolfersdorf C, Keller F et al (2017) Towards a closed carbon cycle and achieving a circular economy for carbonaceous resources. Oil Gas Eur Magazine: 76-80. https://doi.org/10.19225/17060

60. Showa Denko (2015) Showa Denko expands utilization of used plastic to produce ammonia. https:// www.sdk.co.jp/english/news/2015/14469.html. Accessed 27 Jul 2021

61. Meyer B, Keller F, Wolfersdorf C et al (2018) Ein Konzept für die Kohlenstoffkreislaufwirtschaft durch Sektorkopplung zwischen Energie, Chemie \& Abfall. Chem Ing Tec 90:241-248. https://doi. org/10.1002/cite.201700088

62. Lee RP, Laugwitz A, Mehlhose F et al (2018) Waste gasification: Key technology for closing the carbon cycle. 9th International Freiberg Conference on IGCC \& XtL Technologies, Berlin

63. EC (2014) Commission Decision of 18th December 2014 amending Decision 2000/532/EC on the list of waste pursuant to Directive 2008/98/EC of the European Parliament and of the Council: 2014/955/ EU. https://www.umweltbundesamt.de/sites/default/files/medien/2503/dokumente/2014-955-eg-en. pdf. Accessed 27 Jul 2021

64. UBA (2011) Planspiel zur Fortentwicklung der Verpackungsverordnung. https://www.umweltbund esamt.de/sites/default/files/medien/461/publikationen/4074.pdf. ISSN: 18624804. Accessed 05 May 2021

65. Riber C, Petersen C, Christensen TH (2009) Chemical composition of material fractions in Danish household waste. Waste Manage 29:1251-1257. https://doi.org/10.1016/j.wasman.2008.09.013

66. Larsen AW, Vrgoc M, Christensen TH et al (2009) Diesel consumption in waste collection and transport and its environmental significance. Waste Manage Res 27:652-659. https://doi.org/10.1177/ 0734242 X08097636

67. Olesen A (2013) Data extraction from TEMA software for the use in EASETECH V3.1.7 dataset

68. UBA (2018) Energieerzeugung aus Abfällen. https://www.umweltbundesamt.de/sites/default/files/ medien/1410/publikationen/2018-06-26_texte_51-2018_energieerzeugung-abfaelle.pdf. ISSN: 18624359. Accessed 27 Jul 2021

69. Neuwahl F, Cusano G, Benavides JG et al (2019) Best available techniques reference document for waste incineration. https://eippcb.jrc.ec.europa.eu/sites/default/files/2020-01/JRC118637_WI_Bref_ 2019_published_0.pdf. ISSN: 18319424. Accessed 05 May 2021

70. EC (2006) Best available techniques reference document for waste incineration. http://www.prtr-es.es/ data/images/BREF\%20Tratamiento\%20de\%20Residuos-21891D712A33A259.pdf. Accessed 05 May 2021

71. Boldrin A (2012) External process "Wheel loader, combustion 1L of diesel, 2008/2011" in EASETECH V3.1.7 dataset

72. Šyc M, Simon FG, Hykš J et al (2020) Metal recovery from incineration bottom ash: State-of-the-art and recent developments. J Hazard Mater 393:122433. https://doi.org/10.1016/j.jhazmat.2020.122433

73. Harris E, Zeyer K, Kegel R et al (2015) Nitrous oxide and methane emissions and nitrous oxide isotopic composition from waste incineration in Switzerland. Waste Manag 35:135-140. https://doi.org/ 10.1016/j.wasman.2014.10.016

74. Neuwahl F, Cusano G, Benavides JG et al. (2019) Best available techniques reference document for waste incineration. https:/eippcb.jrc.ec.europa.eu/sites/default/files/2020-01/JRC118637_WI_Bref_ 2019_published_0.pdf. ISSN: 18319424. Accessed 01 Apr 2021

75. Fruergaard T, Hyks J, Astrup T (2010) Life-cycle assessment of selected management options for air pollution control residues from waste incineration. Sci Total Environ 408:4672-4680. https://doi.org/ 10.1016/j.scitotenv.2010.05.029

76. Boldrin A (2012) External process "Other drivable machines, combustion 1L of diesel, 2008/2011" in EASETECH V3.1.7 dataset

77. Thinkstep (2019) GaBi Databases 2019 Edition. http://www.gabi-software.com/fileadmin/gabi/ GaBi_Database_19_-Upgrades_and_Improvements.pdf. Accessed 27 Jul 2021

78. UN (2021) Comtrade Database. https://comtrade.un.org/data. Accessed 27 Jul 2021 
79. Montejo C, Tonini D, Márquez MdC et al (2013) Mechanical-biological treatment: performance and potentials. An LCA of $8 \mathrm{MBT}$ plants including waste characterization. J Environ Manage 128:661-673. https://doi.org/10.1016/j.jenvman.2013.05.063

80. VCI (2020) Chemiewirtschaft in Zahlen 2020. https://www.vci.de/vci/downloads-vci/publikation/ chemiewirtschaft-in-zahlen-print.pdf. Accessed 27 Jul 2021

81. BDI (2018) Klimapfade für Deutschland. https://issuu.com/bdi-berlin/docs/20180118_studie_bdi_ klimapfade_fuer/8. Accessed 27 Jul 2021

82. UBA (2007) Beispielhafte Darstellung einer vollständigen, hochwertigen Verwertung in einer MVA unter besonderer Berücksichtigung der Klimarelevanz. https:/www.umweltbundesamt.de/ sites/default/files/medien/publikation/long/3445.pdf. ISSN: 18624804. Accessed 27 Jul 2021

83. UBA (2020) Entwicklung der spezifischen Kohlendioxid Emissionen des deutschen Strommix in den Jahren 1990 - 2019. https:/www.umweltbundesamt.de/sites/default/files/medien/1410/ publikationen/2020-04-01_climate-change_13-2020_strommix_2020_fin.pdf. ISSN: 1862-4359. Accessed 27 Jul 2021

84. BfJ (2020) Gesetz für die Erhaltung, die Modernisierung und den Ausbau der Kraft-Wärme-Kopplung. https://www.gesetze-im-internet.de/kwkg_2016/. Accessed 27 Jul 2021

85. EEX (2021) KWK Index für 2020. https://www.eex.com/de/marktdaten/strom/kwk-index. Accessed 27 Jul 2021

86. Poganietz W-R, Seidl L, Fuss M et al (2019) Nachhaltigkeitsbewertung von Konzepten für die Kohlenstoffkreislaufwirtschaft unter Einbindung der stofflichen Braunkohlenutzung (Kurztitel: StoKo). Schlussbericht. Projektlaufzeit: 01.04.2018-31.08.2019. https://www.tib.eu/de/suchen/ id/TIBKAT:1727670310/Nachhaltigkeitsbewertung-von-Kenzepten-für-die?cHash=90f81d2e0d 86877d4d6f9282744a688c https://www.tib.eu/de/. Accessed 27 Jul 2021

87. DIN (2009) Environmental Management - Life Cycle Assessment - Principles and Framework (ISO 14040:2006); German and English Version EN ISO 14040:2006. Beuth Verlag GmbH, Berlin

88. Clavreul J, Baumeister H, Christensen TH et al (2014) An environmental assessment system for environmental technologies. Environ Model Softw 60:18-30. https://doi.org/10.1016/j.envsoft. 2014.06.007

89. Cobo S, Dominguez-Ramos A, Irabien A (2018) Minimization of Resource Consumption and Carbon Footprint of a Circular Organic Waste Valorization System. ACS Sustainable Chem Eng 6:3493-3501. https://doi.org/10.1021/acssuschemeng.7b03767

90. Maalouf A, El-Fadel M (2019) Life cycle assessment for solid waste management in Lebanon: Economic implications of carbon credit. Waste Manage Res 37:14-26. https://doi.org/10.1177/ $0734242 X 18815951$

91. de Morais Lima P, Olivo F, Paulo PL et al (2019) Life Cycle Assessment of prospective MSW management based on integrated management planning in Campo Grande, Brazil. Waste Manage 90:59-71. https://doi.org/10.1016/j.wasman.2019.04.035

92. Pachauri RK, Mayer L (eds) (2015) Climate change 2014: Synthesis report. Intergovernmental Panel on Climate Change, Geneva, Switzerland. ISBN: 978-92-9169-143-2

93. Huijbregts MAJ, Steinmann ZJN, Elshout PMF et al (2017) ReCiPe2016: a harmonised life cycle impact assessment method at midpoint and endpoint level. Int J Life Cycle Assess 22:138-147. https://doi.org/10.1007/s11367-016-1246-y

94. BMWI (2020) Die Energie der Zukunft. https://www.bmwi.de/Redaktion/DE/Publikationen/Energ ie/achter-monitoring-bericht-energie-der-zukunft.pdf?__blob=publicationFile\&v=14. Accessed 27 Jul 2021

95. EC, (2014) EU energy, transport and GHG emissions: Trends to 2050. Publications Office of the European Union, Luxembourg ISBN: 9789279337284

96. Peters MS, Timmerhaus KD, West RE (2004) Plant design and economics for chemical engineers, 5. ed., internat. ed. McGraw-Hill chemical engineering series. McGraw-Hill, Boston. ISBN: 0072392665

97. Sinnott RK, Towler G (2020) Chemical engineering design, Sixth edition. Coulson and Richardson's chemical engineering series. Elsevier, Amsterdam. ISBN: 9780081025994

98. Friedman J, Fan Z, Byrum Z et al (2020) Levelized cost of carbon abatement: An improved costassessment methodology for a net-zero emissions world. Columbia University CGEP, New York

99. Bator J, Pajak T, Salomon A (2018) Erfahrung bei Planung, Bau und Betrieb der MVA Krakau und Pläne für neue Anlagen in Polen angesichts der Voraussetzungen der Circular Economy. In: Thiel S, Thomé-Kozmiensky E, Quicker P et al (eds) Energy from waste - 15. Thomé-Kozmiensky Verlag GmbH, Nietwerder. ISBN: 9783944310398 
100. Fei F, Wen Z, Huang S et al (2018) Mechanical biological treatment of municipal solid waste: Energy efficiency, environmental impact and economic feasibility analysis. J Clean Prod 178:731-739. https://doi.org/10.1016/j.jclepro.2018.01.060

101. SWB (2020) Müllverbrennung. https://www.swb.de/ueber-swb/unternehmen/nachhaltigkeit/therm ische-verwertung. Accessed 27 Jul 2021

102. Wolfersdorf C (2017) Elektroenergieeinkopplung bei der stofflichen Nutzung von Braunkohle und CO2. Verfahrenstechnik. Dr. Hut, München. ISBN: 9783843933469

103. TA Lauta (2021) Zahlen und Fakten. https://www.t-a-lauta.de/ta-lauta/zahlen-fakten/. Accessed 27 Jul 2021

104. VGB e.V. (2009) Kraftwerksbetrieb im veränderten Marktumfeld: Anforderungen an Personal und Arbeitszeitmodelle. https://www.vgb.org/vgbmultimedia/ANL3_Berechnung_Schichtfaktors_Schic htplangestaltung-p-9170.pdf. Accessed 27 Jul 2021

105. Cucchiella F, D'Adamo I, Gastaldi M (2017) Sustainable waste management: Waste to energy plant as an alternative to landfill. Energy Convers Manage 131:18-31. https://doi.org/10.1016/j.enconman. 2016.11.012

106. BMU (2019) Klimaschutz in Zahlen. https://www.bmu.de/publikation/klimaschutz-in-zahlen-2019/. Accessed 27 Jul 2021

107. Edenhofer O, Flachsland C, Kalkuhl M et al. (2019) Optionen für eine CO2-Preisreform. https:// www.mcc-berlin.net/fileadmin/data/B2.3_Publications/Working\%20Paper/2019_MCC_Optionen_ für_eine_CO2-Preisreform_final.pdf. Accessed 27 Jul 2021

108. BfJ (2020) Körperschaftsteuergesetz. https://www.gesetze-im-internet.de/kstg_1977/. Accessed 27 Jul 2021

109. BdF (2000) AfA-Tabelle für die allgemein verwendbaren Anlagegüter. https://www.bundesfinanzmin isterium.de/Content/DE/Standardartikel/Themen/Steuern/Weitere_Steuerthemen/Betriebspruefung/ AfA-Tabellen/Ergaenzende-AfA-Tabellen/AfA-Tabelle_AV.pdf?__blob=publicationFile \&v=3. Accessed 27 Jul 2021

110. DESTATIS (2020) Volkswirtschaftliche Gesamtrechnungen. https://www.destatis.de/DE/Themen/ Wirtschaft/Volkswirtschaftliche-Gesamtrechnungen-Inlandsprodukt/Publikationen/Downloads-Inlan dsprodukt/inlandsprodukt-vierteljahr-pdf-2180120.pdf?_blob=publicationFile. Accessed 27 Jul 2021

111. DESTATIS (2021) Verbraucherpreisindex (inkl. Veränderungsraten) (61111-0001). https://wwwgenesis.destatis.de/genesis/online. Accessed 27 Jul 2021

112. Stepstone (2021) Jahresgehälter für Technische Angestellte und Ingenieure in Deutschland. https:// www.stepstone.de. Accessed 27 Jul 2021

113. Chen H, Zhang M, Xue K et al (2020) An innovative waste-to-energy system integrated with a coalfired power plant. Energy 194:116893. https://doi.org/10.1016/j.energy.2019.116893

114. UBA (2019) TEHG-Andwendungsbereich - Anwendungsbereich des Treibhausgas-Emissionshandelsgesetzes (TEHG): Hinweise der Deutschen Emissionshandelsstelle (DEHSt). https://www.dehst. de/SharedDocs/downloads/DE/stationaere_anlagen/TEHG-Anwendungsbereich.pdf?_blob=publi cationFile\&v=5. Accessed 27 Jul 2021

115. Koukouzas N, Katsiadakis A, Karlopoulos E et al (2008) Co-gasification of solid waste and lignite - a case study for Western Macedonia. Waste Manage 28:1263-1275. https://doi.org/10.1016/j.wasman. 2007.04.011

\section{Authors and Affiliations}

\section{Raoul Voss $^{1,2,3}$ (D) Roh Pin Lee ${ }^{1}$ (D) Magnus Fröhling $^{3}(\mathbb{D}$}

1 Institute of Energy Process Engineering and Chemical Engineering, Technische Universität Bergakademie Freiberg (TUBAF), Freiberg, Germany

2 Fraunhofer Institute for Microstructure of Materials and Systems IMWS, Branch Lab Freiberg Circular Carbon Technologies, Freiberg, Germany

3 Technical University of Munich (TUM), Munich, Germany 